Article

\title{
Geochronological and Geochemical Constraints on the Formation of the Giant Zaozigou Au-Sb Deposit, West Qinling, China
}

\author{
Hao-Cheng Yu ${ }^{1,2}$, Chang-An Guo ${ }^{1}$, Kun-Feng Qiu ${ }^{1,2,3, * \mathbb{D}}$, Duncan McIntire ${ }^{3} \mathbb{C}$, \\ Gui-Peng Jiang ${ }^{4}$, Zong-Yang Gou ${ }^{1,2}$, Jian-Zhen Geng ${ }^{1}$, Yao Pang ${ }^{1,5}$, Rui Zhu ${ }^{4}$ and Ning-Bo Li ${ }^{2}$ \\ 1 State Key Laboratory of Geological Processes and Mineral Resources, China University of Geosciences, \\ Beijing 100083, China; haochengyu@cugb.edu.cn (H.-C.Y.); gca@cugb.edu.cn (C.-A.G.); \\ zongygou@cugb.edu.cn (Z.-Y.G.); mumu1270@163.com (J.-Z.G.); pangyao1116@163.com (Y.P.) \\ 2 Key Laboratory of Mineralogy and Metallogeny, Guangzhou Institute of Geochemistry, \\ Chinese Academy of Sciences, Guangzhou 510640, China; liningbo@gig.ac.cn \\ 3 Department of Geology and Geological Engineering, Colorado School of Mines, Golden, CO 80401, USA; \\ dmcintire@mymail.mines.edu \\ 4 Zhaojin Mining Industry CO., LTD., Zhaoyuan 265400, China; zzgjianggp@163.com (G.-P.J.); \\ zzgzhurui@163.com (R.Z.) \\ 5 Earthquake Monitoring Center, Sichuan Earthquake Administration, Chengdu 610041, China \\ * Correspondence: kunfengqiu@cugb.edu.cn; Tel.: +86-10-82321383
}

Received: 8 December 2018; Accepted: 2 January 2019; Published: 11 January 2019

check for updates

\begin{abstract}
The Zaozigou Au-Sb deposit has been controversial in its genesis and remains one of the most difficult ore systems to fully understand in West Qinling. The mineralization shows a broad spatial association with Triassic dikes and sills, which were previously thought to be genetically related to mineralization. Our U-Pb zircon dating in this contribution indicates that the ore-hosting porphyritic dacites were formed at $246.1 \pm 5.2 \mathrm{Ma}$ and $248.1 \pm 3.8 \mathrm{Ma}$. The magmatic zircons yield $\varepsilon_{\mathrm{Hf}}(\mathrm{t})$ values ranging from -12.5 to -8.9 , with corresponding two-stage model ages of 2.08 to $1.83 \mathrm{Ga}$. The magma therefore could be derived from partial melting of Paleoproterozoic crustal materials. The ore-hosting porphyritic dacites have low oxygen fugacity, with $\triangle \mathrm{FMQ}$ ranging from -4.61 to -2.56 , indicating that magmas could have been sulfide-saturated during evolution in deep chambers and precluding the possibility that metals were released from the melt. Zaozigou exhibits characteristics widespread volcanics, massive sulfide mineralization, rare reduced mineral assemblage and discrete alteration zones which are not typical of reduced intrusion-related or porphyry gold systems. We propose that the spatially-related Triassic porphyritic dacite and dike swarm is not genetically related to the ore formation of Zaozigou Au-Sb deposit.
\end{abstract}

Keywords: zircon geochronology; magmatic oxygen fugacity; petrogenesis; Zaozigou deposit; West Qinling

\section{Introduction}

The Qinling Orogen linking the Dabie Orogen in the east with the Qilian and the Kunlun Orogens in the west can be separated into the West Qinling and East Qinling segments (Figure 1A) [1-5]. The West Qinling Orogen was assembled by subduction and closure of Palaeozoic Mianlue Ocean between the North China block and South China block during the Late Triassic [4-7]. Triassic granitoids and related mineralization are widespread in the West Qinling and constitute a major target for polymetallic exploration [6-11]. The Tongren-Xiahe-Hezuo district located in the northwest of the West Qinling can be further subdivided into northeastern and southwestern zones 
by the NNW-trending Tongren-Xiahe-Hezuo fault $[6,8]$. The northeastern part hosts several Triassic batholiths and $\mathrm{Cu}-\mathrm{Au}-\mathrm{Fe}$ deposits including Dewulu, Nanban, and Gangyi deposits. The southwestern part consists mainly of Triassic greenschist-facies metasedimentary rocks, which in places have been intruded by porphyry stocks or dikes. Au-Sb deposits such as at Zaozigou, Jiagantan, and Zaorendao can be found hosted in both (meta) sediments and dikes (Figure 1B). The batholiths in the northeastern zone have been dated at 250-235 Ma [6-8] and have been proven to be derived from partial melting of enriched sub-continental lithospheric mantle that had been previously modified by slab-derived melt during the continuous northward subduction of the Paleotethys oceanic slab [6,7,12-15]. The $\mathrm{Cu}-\mathrm{Au}-\mathrm{Fe}$ deposits in the northeastern zone have been recognized as porphyry-skarn systems genetically associated with Early Triassic granitoids [6]. However, a lack of research on felsic stocks and dikes in the southwestern zone makes understanding the dynamic processes governing the formation of the Triassic magmatism difficult. In addition, the genetic relationship between magmatism and ore formation remains controversial.

Successful exploration in the Tongren-Xiahe-Hezuo area relies on a robust understanding of ore deposition mechanisms. Some researchers have proposed that the mineralization is an expression of an intrusion-related gold system based on close spatial and temporal association between gold orebodies and dikes, and geochemical characteristics. Liu et al. [16] suggested that the Zaozigou deposit is a porphyry-type gold deposit related to diorite-porphyry intrusion. Sui et al. [8] and Sui and Li [17] have recently classified Zaozigou as a reduced intrusion-related gold system (RIRGS). Liang et al. [18] and Wei et al. [19] proposed that the activation of faults play important roles in the gold mineralization. Goldfarb et al. [20] believe that the lode gold deposits controlled by faults in metasedimentary rocks in this area are best classified as orogenic gold deposits. Porphyry deposits are spatially, temporally, and genetically related to hypabyssal dioritic to granitic intrusions. They are characterized by ore minerals in veinlets and disseminations in large volumes of hydrothermally altered rock [21]. The RIRGS model is as yet poorly defined. They are coeval ( $\pm 2 \mathrm{Ma})$ with their associated, causative felsic and ilmenite-series pluton [22]. The most distinctive mineralization style of RIRGS is sheeted veins, which are composed of parallel, low-sulfide content, single stage quartz veins. Most orogenic gold deposits occur in greenschist facies rocks and are located adjacent to first-order, deep-crustal fault zones [23]. In Orogenic gold deposits ore minerals are deposited as vein fill of second- and third-order shears and faults, particularly at jogs or changes in strike along the crustal-scale fault zones.

The Zaozigou Au-Sb deposit is the largest gold deposit in the Tongren-Xiahe-Hezuo area (Figure 1B). Gold mineralization is controlled by fault systems, with primary mineralization manifesting as vein-hosted lode deposits. Secondary mineralization is primarily defined by wallrock alteration of intermediate to felsic dikes and Triassic slate host rocks, making it amenable to a comprehensive dike and ore genesis study. In this contribution, we performed LA-ICP-MS U-Pb dating, trace element analysis, and Lu-Hf isotope determination on zircons separated from ore-hosting porphyritic dacite at Zaozigou. Together with $\mathrm{U}-\mathrm{Pb}$ ages, $\varepsilon_{\mathrm{Hf}}(\mathrm{t})$, and oxygen fugacity values from the Triassic granitoids in the Tongren-Xiahe-Hezuo area, we evaluate their emplacement timing and petrogenesis in an attempt to elucidate the relationship between magmatism and mineralization. 


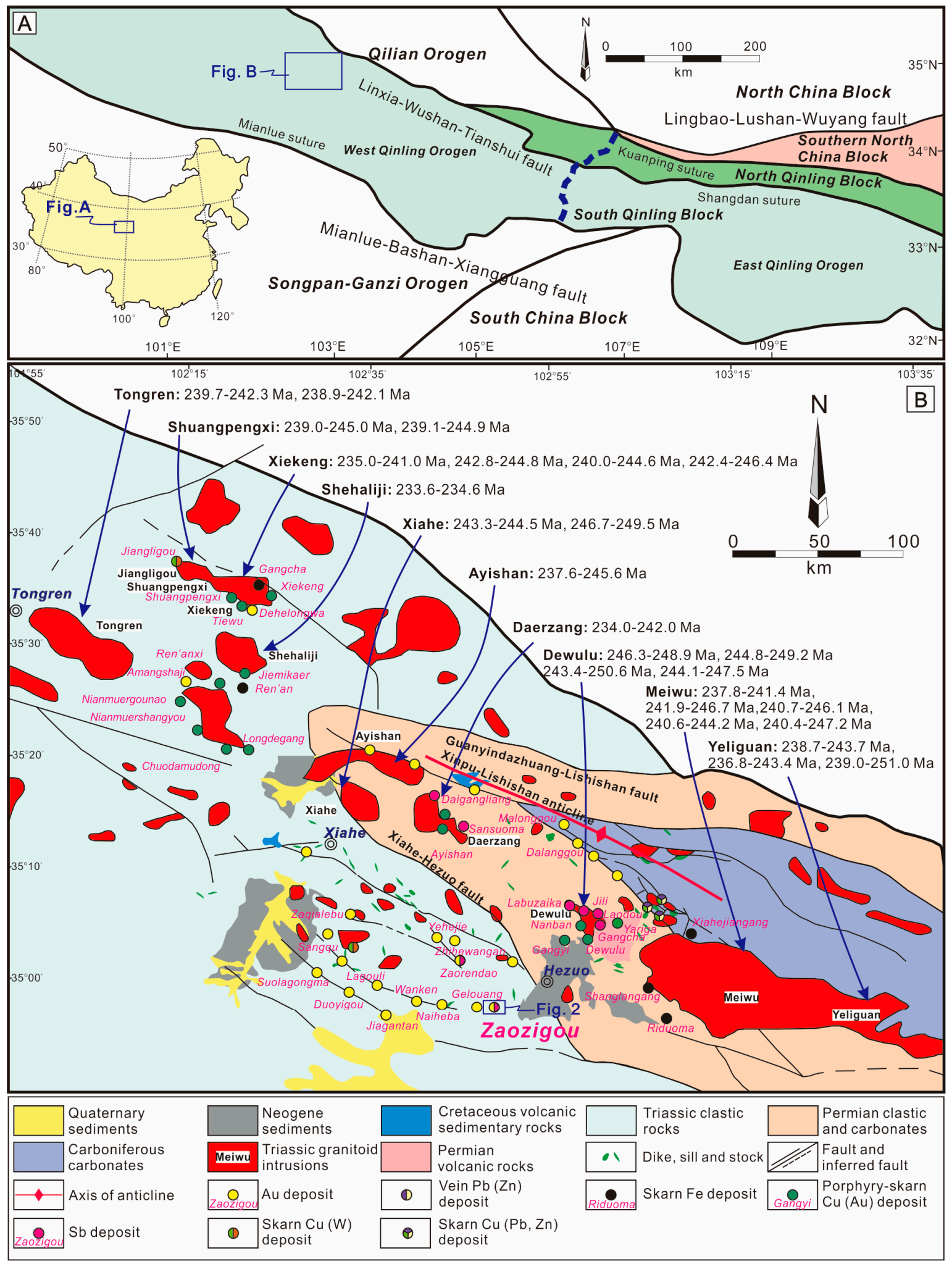

Figure 1. (A) Major tectonic domains of China and the location of the Qinling Orogenic Belt. Inset shows the location of the study area (modified after [6]). (B) Simplified geological map of the Tongren-Xiahe-Hezuo area of the Western Qinling Orogen, showing distributions and ages of early Triassic granitoids and ore deposits (modified after [6]). 


\section{Geological Background}

\subsection{Regional Geology}

The Qinling Orogen in central China extends east-west for over $1500 \mathrm{~km}$ and is a major portion of the Central China Orogenic Belt $[1,4,5,14,24,25]$. It is tectonically bounded by the Qilian Orogen and North China block marked by the Lingbao-Lushan-Wuyang fault to the north, and Songpan-Ganzi Orogen and South China block marked by the Mianlue-Bashan-Xiangguang fault suture to the south (Figure 1A) $[1,3,15]$. The Qinling Orogen is generally further separated into the southern North China block, North Qinling block, South Qinling block and northern South China block from north to south by the Kuanping suture, Shangdan suture and Mianlue suture with related faults (Figure 1A) [2,3,10,24]. The Neoproterozoic Kuanping suture zone hosts greenschist and amphibolite facies rocks, which reflect remnants of an oceanic crust and oceanic island basalt of the Kuanping Ocean inferred to have existed at least during ca. 1.45-0.95 Ga [24]. The Paleozoic Shangdan suture zone mainly comprises ophiolitic assemblages, and subduction-related volcanic and sedimentary rocks, which are considered to have been associated with closure of the Shangdan Ocean and multistage amalgamation of the South China block-South Qinling block to the North China block during the Paleozoic $[7,24]$. The Triassic Mianlue suture zone is characterized by discontinuously exposed ophiolite sequences, ocean-island basalt, and island-arc volcanic rock units, marking the closure of a northern branch of the eastern Paleotethyan Ocean [1,7,24-28].

The West Qinling Orogen has traditionally been separated by the Huicheng basin or Foping dome roughly along the Baoji-Chengdu railway (shown as blue dash line in Figure 1A) to the East Qinling Orogen [7-10]. It is interpreted to have undergone a three-stage amalgamation process between the South and North China blocks, which include an early to middle Paleozoic accretionary orogen along the southern side of the North China block, a late Paleozoic to Triassic collisional orogen along the Mianlue suture zone, with amalgamation of the South China block to earlier accreted terranes, and Jurassic to Cretaceous intracontinental tectonism [7,24]. Sedimentary cover in West Qinling is dominated by Devonian to Cretaceous sediments and Precambrian basement is rarely exposed $[5,8]$. The pervasively folded and faulted strata record deformation related to the subduction and collision history $[8,10]$. The magmatism is widespread in West Qinling, including several dozens of Triassic granitoid intrusions in the eastern part and early to middle Triassic granitoids in the western part $[5,8]$. The intrusions in the eastern part corresponding to superimposed orogeny evolved from the northward subduction of Paleotethys Ocean through syn-collision to post-collision between the North China and South China blocks [7]. The granitoids in the western part were derived from arc magmatism related to an active continental margin setting [6].

The Tongren-Xiahe-Hezuo area is located to the northwestern segment of the West Qinling orogen (Figure 1A). This region hosts outcrops of late Paleozoic to early Mesozoic greenschist-facies slate, Triassic intrusions, with minor occurrences of Permian volcanic rocks and Cretaceous volcanic-sedimentary rocks (Figure 1B). The fine-grained foliated slate has been metamorphosed from original clastic rocks and volcanics. These rocks are mainly composed of quartz, feldspar and muscovite. Mesozoic igneous rocks, granitic stocks, dikes, and sills are widespread in the Xiahe-Hezuo district, and have been well documented to be closely-related spatially to hydrothermal ore deposits and occurrences (Figure 1B) [6,14].

\subsection{Geology of the Zaozigou Deposit}

The giant Zaozigou Au-Sb deposit ( $\left.34^{\circ} 57^{\prime} 56^{\prime \prime} \mathrm{N}, 102^{\circ} 48^{\prime} 41^{\prime \prime} \mathrm{E}\right)$ is one of the largest gold deposits in the West Qinling. The estimated pre-mining resources included $106 \mathrm{t} \mathrm{Au}$ at an average grade of $3.34 \mathrm{~g} / \mathrm{t}$, and over $0.13 \mathrm{Mt} \mathrm{Sb}$ at an average grade of $1.34 \mathrm{~g} / \mathrm{t}[8,16,29-33]$. It is located about $9 \mathrm{~km}$ west of Hezuo City in Gansu Province (Figure 1B). The deposit was discovered in 1996 and has been mined since 2001 by the Zaozigou Gold Company. It was mined for oxidized ores by open pit prior to 2009 and subsequently by underground operations. Present annual production is about $3 \mathrm{t}$ Au. 
The Triassic Gulangdi Formation is the main host for the deposit (Figure 2). These rocks, which account for $70 \%$ of the outcrop area, are mainly composed of siliceous slate, calcareous slate, quartz sandstone, and siltstone [8,16-19]. Numerous NE- and NNE-trending intermediate to felsic sills and dikes intrude the regional greenschist facies meta-sedimentary rocks. These sills and dikes also host $\mathrm{Au}-\mathrm{Sb}$ ore, and consist of porphyritic dacite, granodiorite, and porphyritic rhyolite. Previous age estimates suggest these igneous rocks vary from 250 to $215 \mathrm{Ma}[8,16]$. Four deformation events have been recognized. D1: NE-trending compression that produced NW-trending folds and thrusts, induced NS-, NE-, and nearly EW-trending fractures, and controlled emplacement of NE-trending dikes. D2: NE-, NNE-, NS-trending brittle faults. D3: Low-angle nearly EW-trending faults. D4: NNE-trending left-lateral transtensional faults that locally cut orebodies. The D2 and D3 stages are the main deformational events associated with the ores [8,16-19].

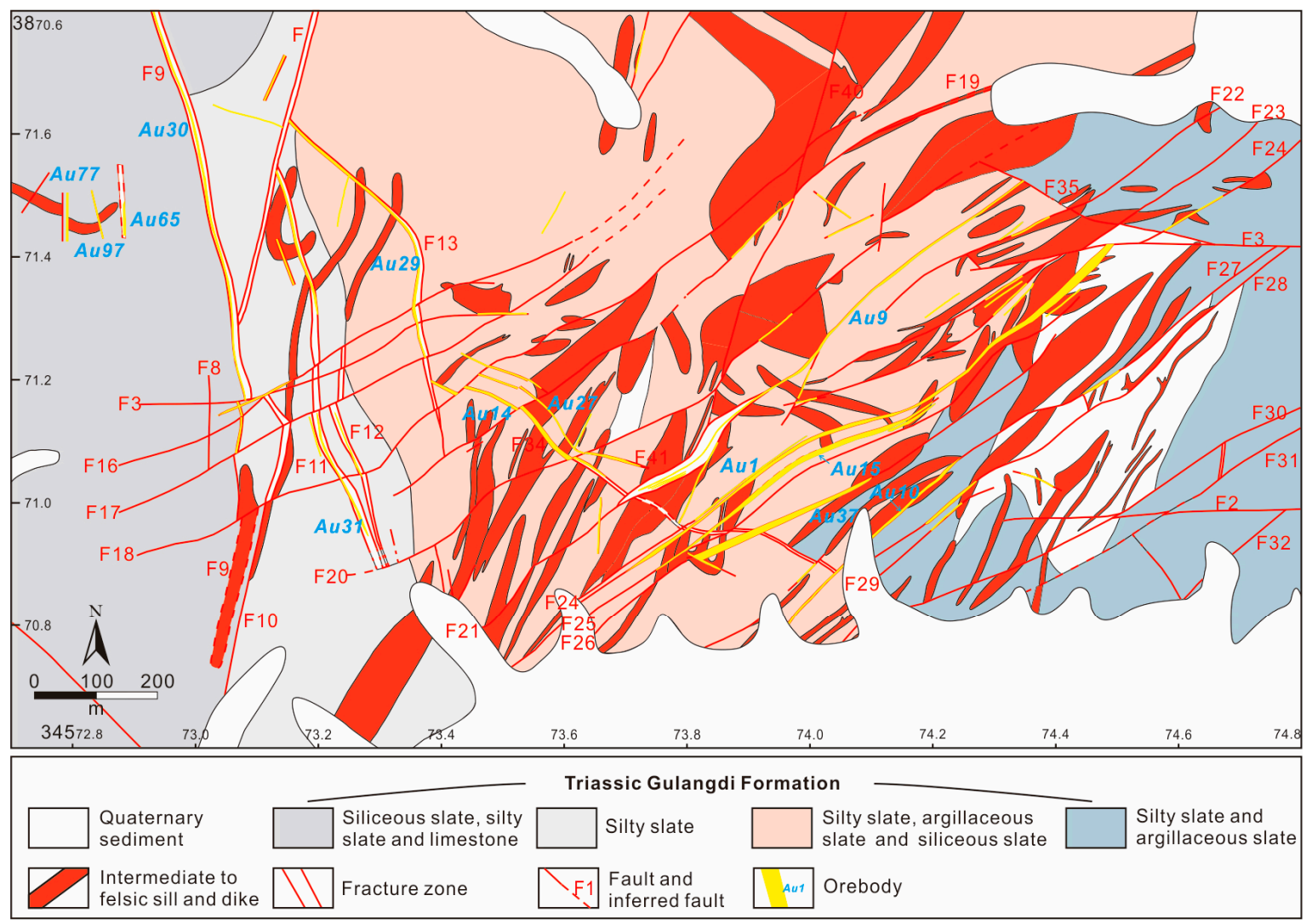

Figure 2. Sketch geologic map of the giant Zaozigou Au-Sb deposit in the West Qinling, China.

The ore-bearing zones comprise disseminated and veinlet ores within altered dikes (Figure 3A,B) and slates (Figure $3 \mathrm{C}, \mathrm{D}$ ), and gold- and/or stibnite-rich quartz \pm calcite load vein mineralization (Figure 3E-H). They are structurally controlled by the NE-, NS-, and NW-trending faults, and are characterized by strong sulfidation (pyrite, arsenopyrite, stibnite), sericitization, silicification, and carbonatization in the wallrocks. Some of the gold- and stibnite-rich quartz \pm calcite veins are also structurally controlled by low-angle $\mathrm{E}-\mathrm{W}$ faults. The iron-rich minerals or wallrock are important chemical traps for ore mineralization through wall rock sulfidation reactions (Figure 3A-D). The ore minerals in addition to the abundant stibnite, include lesser amounts of pyrite, arsenopyrite, sphalerite, chalcopyrite, tetrahedrite, galena, and native gold. The gangue minerals consist of quartz, biotite, calcite, sericite, feldspar, and epidote, with minor apatite, titanite, zircon, and monazite. Native gold grains occur in cracks or as inclusions within stibnite and quartz. Invisible gold is present in pyrite and arsenopyrite. Four paragenetic stages are identified based on crosscutting relationships and mineralogical and textural 
characteristics: stage 1 pyrite-chalcopyrite-tetrahedrite-quartz, stage 2 pyrite-arsenopyrite-quartz, stage 3 stibnite-sphalerite-quartz-native gold, and stage 4 stibnite-quartz-calcite (Figure 4).
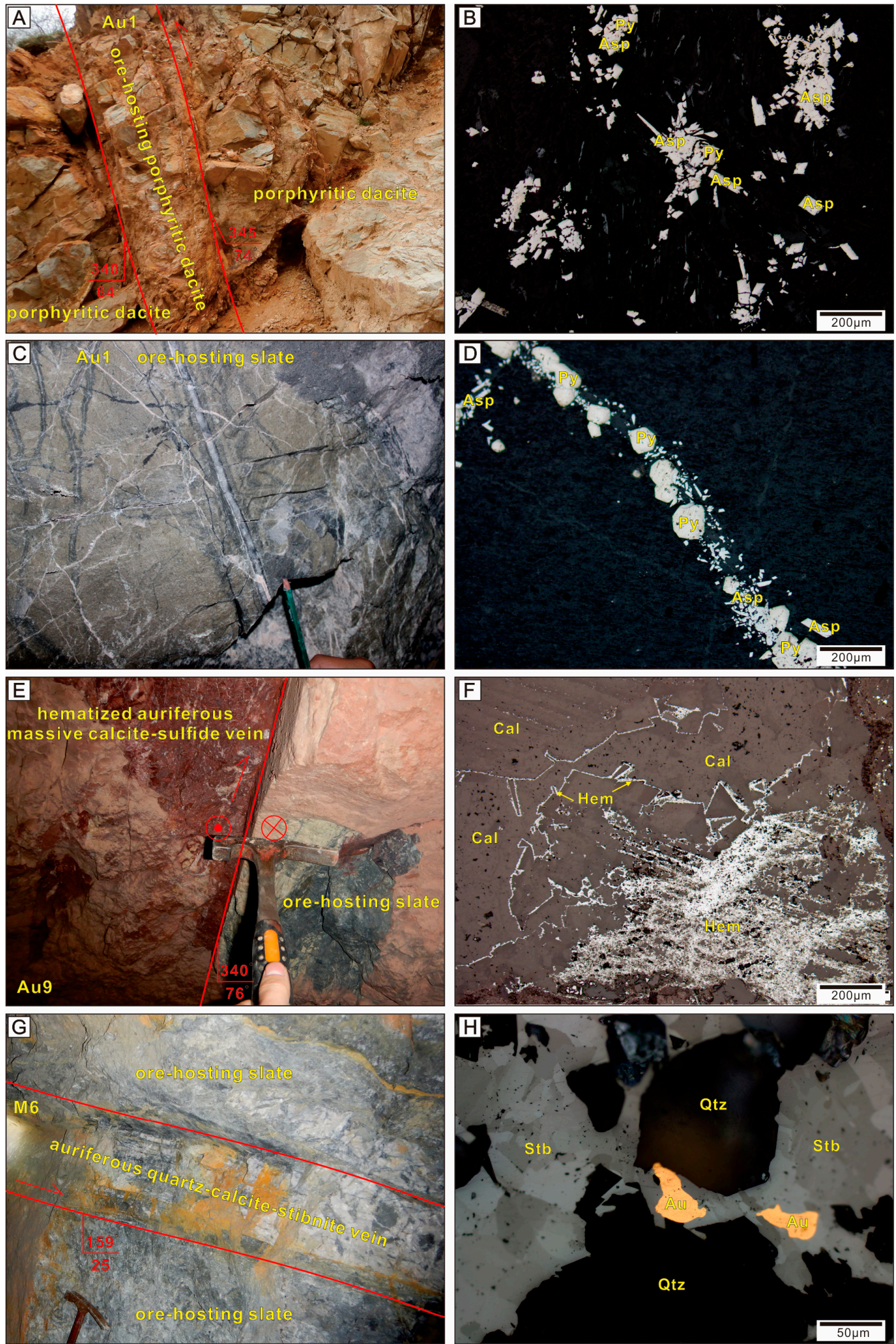

Figure 3. Exposure $(\mathbf{A}, \mathbf{C}, \mathbf{E}, \mathbf{G})$ and photomicrographs under reflected light $(\mathbf{B}, \mathbf{D}, \mathbf{F}, \mathbf{H})$ showing mineralization styles and mineral assemblages. (A,B) Pyrite and arsenopyrite as disseminated 
aggregates in porphyritic dacite. (C,D) Pyrite and arsenopyrite veinlet in slate. (E,F) Hematized auriferous calcite veins. (G,H) Auriferous quartz-calcite-stibnite vein structurally controlled by NE-trending faults cutting slate and native gold grains occur in cracks and inclusions of stibnite and quartz. Py = pyrite, $\mathrm{Asp}=$ arsenopyrite, $\mathrm{Stb}=$ stibnite, $\mathrm{Au}=$ native gold, $\mathrm{Qtz}=$ quartz, $\mathrm{Cal}=$ calcite, Hem $=$ hematite .

One hundred and forty-three orebodies have been delineated over the life of the mine, 16 of which have an individual reserves exceeding $1 \mathrm{t}$ Au. The Au1, Au9 and M6 gold orebodies comprise over $40 \%$ of the Zaozigou deposit gold endowment. The Au1 and Au9 orebodies, which together comprise $33 \%$ of the gold endowment, are controlled by the NE-trending faults. The largest orebody, Au1 (pre-ore reserves $20 \mathrm{t} \mathrm{Au}$ ), is controlled by the F24 fault, which is characterized by multiphase activity and varying fault movement sense. The Au1 orebody consists of disseminated, veinlet, and auriferous quartz-stibnite ores (Figure 3A-D). The orebody developed in the porphyritic dacites dikes and slate, and known to extend along strike for at least $1240 \mathrm{~m}$, with a trend of $55^{\circ}$ and a dip of $80^{\circ}$ to $85^{\circ}$. It ranges in thickness from 0.82 to $18.13 \mathrm{~m}$ (avg. $3.48 \mathrm{~m}$ ) and extends downdip at least $1200 \mathrm{~m}$. The gold grade varies from 1.00 to $11.20 \mathrm{~g} / \mathrm{t}$ with an average of $3.47 \mathrm{~g} / \mathrm{t}$. The Au9 orebody hosts pre-ore reserves $15 \mathrm{t} \mathrm{Au}$. Au9 is spatially controlled by the F21 fault, parallel with the Au1 orebody. It is hosted entirely within the slate and is characterized by hematized auriferous calcite veins. Au9 lode veins are mainly composed of coarse-grained calcite (1-8 cm interlocking crystals). The Au 9 orebody is $800 \mathrm{~m}$ long and 0.44 to $11.36 \mathrm{~m}$ thick (avg. $2.24 \mathrm{~m}$ ), trending $55^{\circ}$ and dipping $\sim 80^{\circ}$ (Figure 3E,F). The gold grade varies from 1.02 to $21.90 \mathrm{~g} / \mathrm{t}$ with an average of $3.46 \mathrm{~g} / \mathrm{t}$. The M6 concealed orebody controlled by the EW-trending fault F3 contains 15 t Au. M6 cross-cuts the Au1 and Au9 orebodies. The orebody is characterized by auriferous quartz-calcite-stibnite vein ores and appears as stratiform-like lenses that strike $165^{\circ}$ to $180^{\circ}$ and dip $10^{\circ}$ to $26^{\circ}$ (Figure $3 \mathrm{G}, \mathrm{H}$ ). It is $1160 \mathrm{~m}$ long, extending downdip from the 3226-m level to the 3030-m level, and ranges in thickness from $0.94 \mathrm{~m}$ to $15.87 \mathrm{~m}$ with an average thickness of $3.94 \mathrm{~m}$. The gold grade varies from 1.01 to $12.97 \mathrm{~g} / \mathrm{t}$ with an average of $4.01 \mathrm{~g} / \mathrm{t}$.

\begin{tabular}{|c|c|c|c|c|c|c|c|c|c|c|c|}
\hline Mineral & \multicolumn{4}{|c|}{ Stage 1} & \multicolumn{2}{|r|}{ Stage 2} & \multicolumn{2}{|r|}{ Stage 3} & \multicolumn{3}{|c|}{ Stage 4} \\
\hline pyrite & - & = & ש & E & - & & & & E & $=0$ & E \\
\hline chalcopyrite & E & = & 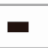 & $=$ & 1 & & & & & & \\
\hline tetrahedrite & - & - & - & - & , & & & & & & \\
\hline arsenopyrite & & & & & E & & E & $=0$ & - & $=$ & - \\
\hline stibnite & & & & & & & E & & & & \\
\hline sphalerite & & & & & & & E & $=0$ & $\theta$ & & \\
\hline native gold & & & & & & & E & 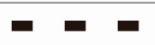 & , & & \\
\hline quartz & e & - & - & - & - & $=0$ & & & & & \\
\hline calcite & & & & & & & & & & & \\
\hline
\end{tabular}

Figure 4. Paragenetic sequence of the Zaozigou deposit interpreted from cross-cutting relationships, ore textures and sulfide assemblages. The black full lines indicate high abundance and the black dashed lines represent minor amounts.

\section{Sampling and Analytical Methods}

\subsection{Sampling}

The detailed investigations of the present study focus on the porphyritic dacite dikes in the Zaozigou deposit. Representative samples were collected from the wallrock of the \#Au1 orebody. The porphyritic dacite samples (ZZG11 and ZZG12) are light green to buff in color texture (Figure 5A,C). The phenocrysts include quartz (15-20 vol \%, long dimension 0.1-1.5 mm), plagioclase (5-15 vol \%, long dimension $0.1-2.5 \mathrm{~mm}$ ), and biotite (5-15 vol \%, long dimension $0.1-2 \mathrm{~mm})$. Some quartz grains 
show rounded or angular-crystal habit, with dissolution textures. The plagioclase and biotite grains are variably altered to fine sericite and chlorite. The groundmass consists of plagioclase, quartz, and minor K-feldspar. Accessory minerals are mainly zircon, apatite, epidote, chlorite, and sericite (Figure 5B,D). Ore mineralogy consists mainly of pyrite and arsenopyrite, which are commonly sitting in iron-rich minerals, notably biotite which has been hydrothermally altered to sericite or chlorite (Figure 5B,D).
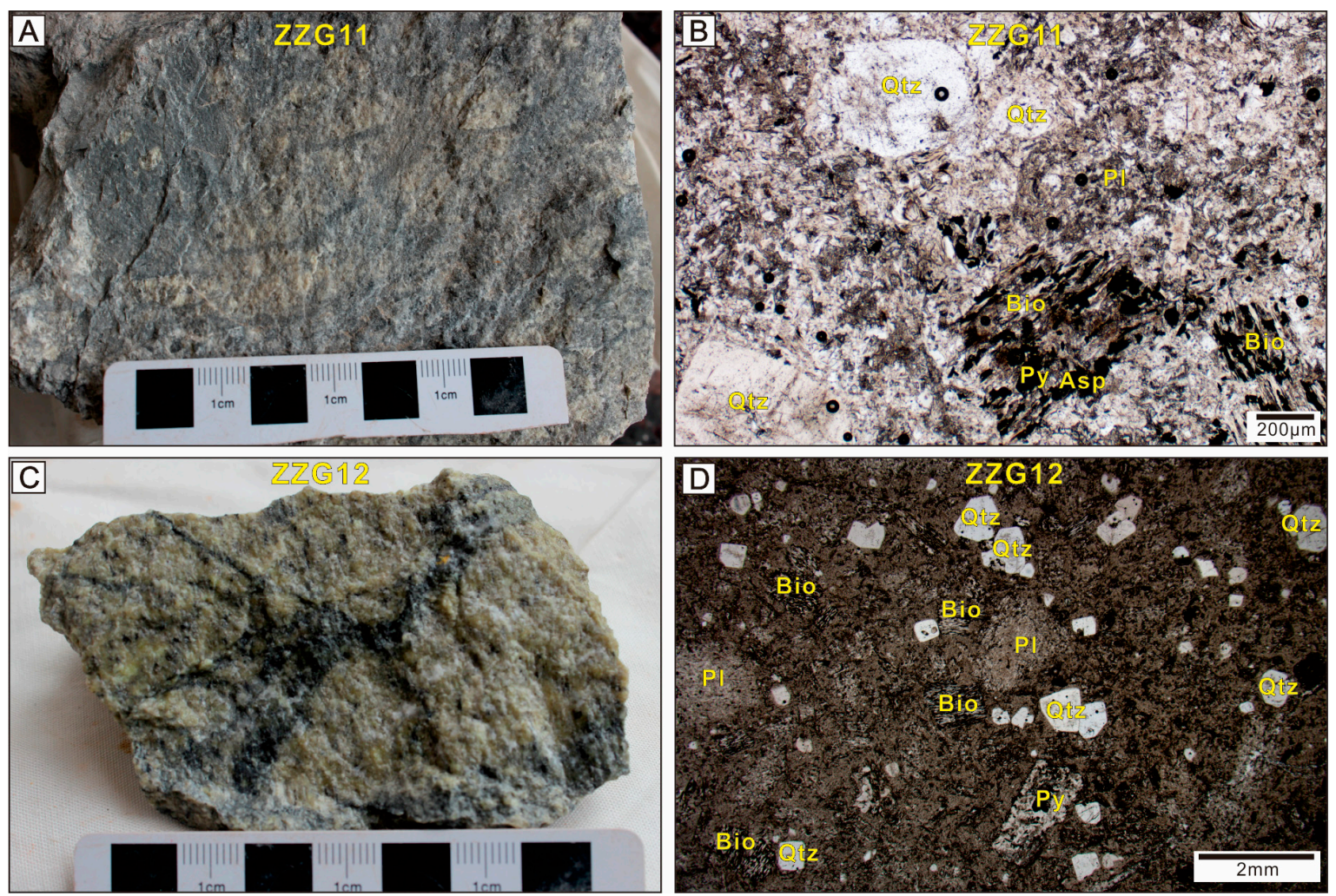

Figure 5. Hand specimen $(\mathbf{A}, \mathbf{C})$ and photomicrographs under transmitted light $(\mathbf{B}, \mathbf{D})$ of porphyritic dacite in this study. Py = pyrite, Asp = arsenopyrite, Bio = biotite, $\mathrm{Pl}=$ plagioclase, $\mathrm{Qtz}=$ quartz, Cal = calcite.

\subsection{Analytical Methods}

\subsubsection{Zircon LA-ICP-MS U-Pb Dating and Trace Element Analyses}

The porphyritic dacite samples were crushed to 40-60 mesh, and zircon crystals were separated through standard magnetic and density separation techniques. Zircon grains were carefully handpicked under a binocular microscope, mounted in epoxy, polished down to near half sections to expose internal structures, and then cleaned in an ultrasonic washer containing a $5 \% \mathrm{HNO}_{3}$ bath. Prior to analysis, polished sections of zircon were carbon coated for cathodoluminescence (CL) imaging, which were taken on a JXA-880 electron microscope and an image analysis software was used under operating conditions of $20 \mathrm{kV}$ and $20 \mathrm{nA}$, at the Institute of Mineral Resources, Chinese Academy of Geological Sciences, Beijing, China, to identify the internal structure and texture of all zircon crystals. Zircon samples are checked carefully under the microscope and scanning electron microscope (SEM) to observe mineral and fluid inclusions and cracks.

Zircon $\mathrm{U}-\mathrm{Pb}$ isotope and trace element analyses were simultaneously carried out using a LA-ICP-MS system in the Key Laboratory of Mineralogy and Metallogeny, Guangzhou Institute of Geochemistry, the Chinese Academy of Sciences. The LA-ICP-MS system includes an Agilent 7900 ICP-MS coupled with a Resonetics RESOlution S-155 ArF-Excimer laser source $(\lambda=193 \mathrm{~nm})$. The operating conditions were $4 \mathrm{~J} / \mathrm{cm}^{2}$ of energy density, $29 \mu \mathrm{m}$ of spot diameter, and $8 \mathrm{~Hz}$ of ablation frequency. Plesovice zircon, a new natural reference material for $\mathrm{U}-\mathrm{Pb}$ isotopic 
microanalysis, was analyzed once every five analyses and TEMORA zircon was used as internal standards for $\mathrm{U}-\mathrm{Pb}$ dating, and was analyzed twice every five analyses, in order to normalize isotopic fractionation during isotope analysis. The NIST610 glass standard was used as an external standard to normalize $\mathrm{U}$, $\mathrm{Th}$, and $\mathrm{Pb}$ concentrations of the unknowns. In addition, standard sample mud tank was used as an isotopic monitoring sample. The ICPMS DataCal program was used for processing analyses data. Common $\mathrm{Pb}$ was corrected according to the method proposed by [34]. The analytical results are reported with $1 \sigma$ error. The weighted mean $\mathrm{U}-\mathrm{Pb}$ ages (with $90 \%$ confidence) were calculated at $2 \sigma$ level and Concordia plots were produced using ISOPLOT $3.23 \mathrm{~V}$. The ${ }^{29} \mathrm{Si}$ was used as an internal standard for trace element analyses. The average analytical error ranges from $10 \%$ for light rare earth elements (LREE) to 5\% for other trace elements. A detailed compilation of instrument and data acquisition parameters was presented in [35].

\subsubsection{In Situ Zircon Lu-Hf Isotope Analyses}

In situ zircon Lu-Hf isotopic analysis was carried out across samples on the analogous zircon zones where $\mathrm{U}-\mathrm{Pb}$ age determinations were made. Hafnium isotopic compositions were determined with a Thermo Finnigan Neptune MC-ICP-MS system coupled to a New Wave UP193 nm laser ablation system at the Laboratory of Isotope Geology, Tianjin Institute of Geology and Mineral Resources, Tian-jin, China. A laser repetition rate of $11 \mathrm{~Hz}$ at $100 \mathrm{~mJ}$ was used for ablating zircons and the spot diameters were $50 \mu \mathrm{m}$. Helium was used as the carrier gas for the ablated aerosol. Isotopes, including ${ }^{177} \mathrm{Hf},{ }^{178} \mathrm{Hf},{ }^{179} \mathrm{Hf},{ }^{180} \mathrm{Hf},{ }^{172} \mathrm{Yb},{ }^{173} \mathrm{Yb},{ }^{175} \mathrm{Lu},{ }^{176}(\mathrm{Hf}+\mathrm{Yb}+\mathrm{Lu})$, and ${ }^{182} \mathrm{~W}$, were measured during the analytical process. Isobaric interference of ${ }^{176} \mathrm{Lu}$ on ${ }^{176} \mathrm{Hf}$ was corrected based on the measured ${ }^{175} \mathrm{Lu}$ value and the recommended ${ }^{176} \mathrm{Lu} /{ }^{175} \mathrm{Lu}$ ratio of 0.02655 . Similarly, the ${ }^{176} \mathrm{Yb} /{ }^{172} \mathrm{Yb}$ value of 0.5887 and mean $\beta \mathrm{Yb}$ value obtained during $\mathrm{Hf}$ analysis on the same spot were used for interference correction of ${ }^{176} \mathrm{Yb}$ on ${ }^{176} \mathrm{Hf}$. During the analyses, the GJ-1zircon standard yielded ${ }^{176} \mathrm{Hf} /{ }^{177} \mathrm{Hf}$ ratios of $0.282009 \pm 24(2 \sigma, \mathrm{n}=13)$. These ratios are consistent with the recommended ${ }^{176} \mathrm{Hf} /{ }^{177} \mathrm{Hf}$ ratios of $0.282015 \pm 19$. The decay constant for ${ }^{176} \mathrm{Lu}$ of $1.865 \times 10^{-11}$ year ${ }^{-1}$ and present-day chondritic ratios of ${ }^{176} \mathrm{Hf} /{ }^{177} \mathrm{Hf}=0.282785$ and ${ }^{176} \mathrm{Lu} /{ }^{177} \mathrm{Hf}=0.0336$ were used to calculate the $\varepsilon_{\mathrm{Hf}}(\mathrm{t})$ values [35-37].

\subsubsection{Magmatic Oxygen Fugacity Estimation}

Zou et al. [38] reviewed the underlying assumption of zircon REE oxy-barometers, the lattice strain model, systematically re-evaluated the common zircon REE oxy-barometers, and concluded that the $x_{\mathrm{Ce} e^{4+}}^{m e l t} / x_{C e^{3+}}^{m e l t}$ oxy-barometer is a reliable accurate measurement. Oxygen fugacities in this study were estimated by algorithm based on MATLAB software using the formula (Computer Code S1 in Supplementary Materials) [39]

$\ln \left(\frac{x_{C e^{4+}}^{m e l t}}{x_{C e^{3+}}^{m e l t}}\right)=\frac{1}{4} \ln f \mathrm{O}_{2}+\frac{13136( \pm 591)}{T}-2.604( \pm 0.011) \frac{N B O}{T}-8.878( \pm 0.112) \cdot x \mathrm{H}_{2} \mathrm{O}-8.955( \pm 0.091)$

where $x_{\mathrm{Ce}^{4+}}^{\text {melt }} / x_{\mathrm{Ce} e^{3+}}^{\text {melt }}$ can be determined using the lattice strain model [40], $T$ is the zircon crystallization temperature in $\mathrm{K}$ following the Ti-in-zircon thermometer and using a $\mathrm{TiO}_{2}$ activity of 0.6 and $\mathrm{SiO}_{2}$ activity of 1 [41], NBO/ $\mathrm{T}$ is the proportion of non-bridging oxygen to tetrahedrally coordinated cations and can be determined on an anhydrous basis [42], and $x_{2} \mathrm{O}$ is the mole fraction of water dissolved in the melt. In general, the water content of felsic magma is assumed to be 2.5-6.5 wt \%. On the other hand, amphibole grain is rare in porphyritic dacite, indicating the water content is less than $4.5 \mathrm{wt} \%$. Therefore, the water content is assumed to be $3 \mathrm{wt} \%$ in this paper $[39,43]$. 


\section{Analytical Results}

\subsection{Zircon Morphology and U-Pb Ages}

Most zircon grains are pristine, euhedral and display well-developed oscillatory growth zoning. Some crystals display inherited zircons with weak zoning or no zoning and some have mineral inclusions including apatite and zircon. The crystals have lengths of 100-200 $\mu \mathrm{m}$ and length/width ratios of 2:1 to 3:1. Several grains contain zircon and apatite inclusions, and have jagged edges, indicating that they may have been hydrothermally altered (Figure 6).

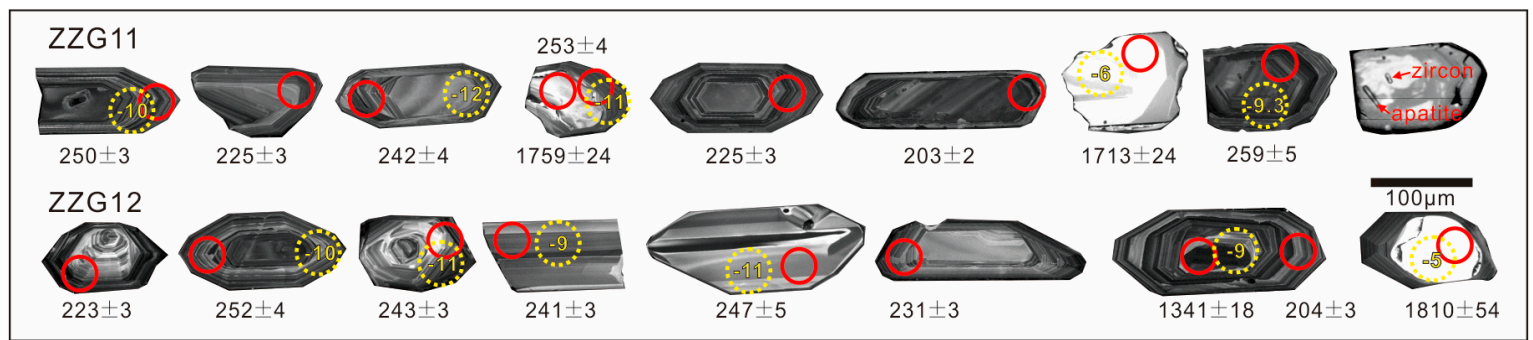

Figure 6. Representative cathodoluminescence images and photomicrographs of zircons derived from ZZG11 and ZZG12 with identified analytical spot, U-Pb age (Ma) and $\varepsilon_{\mathrm{Hf}}(\mathrm{t})$ value. Red circle: $\mathrm{U}-\mathrm{Pb}$ beam. Yellow dash circle: Hf beam.

Twenty-five analyses were carried out for $\mathrm{U}-\mathrm{Pb}$ age dating of zircons from sample ZZG11 (Table 1, Figure 7A-C). Two analyses on the inherited zircons give ${ }^{206} \mathrm{~Pb} /{ }^{238} \mathrm{U}$ ages of $1759 \pm 24$, and $1713 \pm 24 \mathrm{Ma}$, respectively. Twenty analyses are concordant, yielding weighted average ages of $248.1 \pm 3.8 \mathrm{Ma}(\mathrm{MSWD}=3.6, \mathrm{n}=14), 222.1 \pm 4.4 \mathrm{Ma}(\mathrm{MSWD}=1.4, \mathrm{n}=5)$, and $203.5 \pm 2.2 \mathrm{Ma}$ $(\mathrm{n}=1)$, respectively.
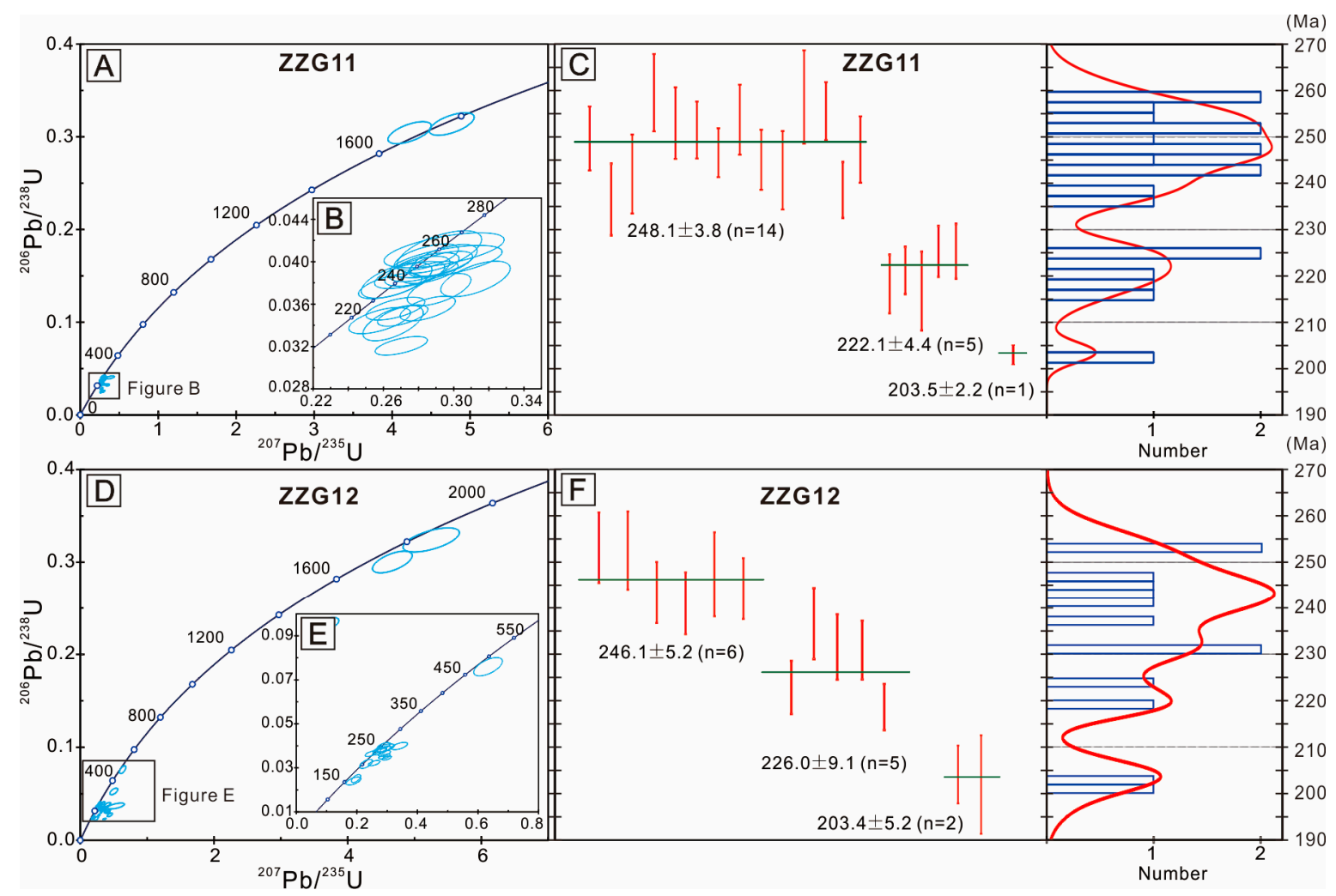

Figure 7. LA-ICP-MS zircon U-Pb concordia diagrams for ZZG11 (A-C) and ZZG12 (D-F). 
Twenty analyses were carried out for $\mathrm{U}-\mathrm{Pb}$ age dating of zircons from sample ZZG12 (Table 1, Figure 7D-F). Four analyses on the inherited zircons give ${ }^{206} \mathrm{~Pb} /{ }^{238} \mathrm{U}$ ages of $1810 \pm 26,1693 \pm 24,1341 \pm 18$, and $472 \pm 10$, respectively. Thirteen analyses are concordant, yielding weighted average ages of $246.1 \pm 5.2 \mathrm{Ma}(\mathrm{MSWD}=1.8, \mathrm{n}=6), 226.0 \pm 9.1 \mathrm{Ma}(\mathrm{MSWD}=5.6$, $\mathrm{n}=5)$, and $203.4 \pm 5.2 \mathrm{Ma}(\mathrm{MSWD}=0.12, \mathrm{n}=2)$, respectively.

Table 1. LA-ICP-MS zircon U-Pb dating results of porphyritic dacite samples ZZG11 and ZZG12.

\begin{tabular}{|c|c|c|c|c|c|c|c|c|c|c|c|c|}
\hline \multirow{3}{*}{ Sample No. } & \multicolumn{6}{|c|}{ Isotopic Ratios } & \multicolumn{6}{|c|}{ Ages (Ma) } \\
\hline & \multicolumn{2}{|c|}{${ }^{207} \mathrm{~Pb} /{ }^{206} \mathrm{~Pb}$} & \multicolumn{2}{|c|}{${ }^{207} \mathrm{~Pb} /{ }^{235} \mathrm{U}$} & \multicolumn{2}{|c|}{${ }^{206} \mathrm{~Pb} /{ }^{238} \mathrm{U}$} & \multicolumn{2}{|c|}{${ }^{207} \mathrm{~Pb} /{ }^{206} \mathrm{~Pb}$} & \multicolumn{2}{|c|}{${ }^{207} \mathrm{~Pb} /{ }^{235} \mathrm{U}$} & \multicolumn{2}{|c|}{${ }^{206} \mathrm{~Pb} /{ }^{238} \mathrm{U}$} \\
\hline & Ratio & $1 \sigma$ & Ratio & $1 \sigma$ & Ratio & $1 \sigma$ & Age & $1 \sigma$ & Age & $1 \sigma$ & Age & $1 \sigma$ \\
\hline \multicolumn{13}{|c|}{ ZZG11: Inherited Zircon } \\
\hline ZZG11.9 & 0.1097 & 0.0020 & 4.7641 & 0.1176 & 0.3138 & 0.0050 & 1794.8 & 33.3 & 1778.6 & 20.8 & 1759.2 & 24.3 \\
\hline ZZG11.11 & 0.1009 & 0.0027 & 4.2254 & 0.1139 & 0.3044 & 0.0048 & 1640.4 & 54.6 & 1679.0 & 22.2 & 1713.2 & 24.0 \\
\hline \multicolumn{13}{|c|}{ ZZG11: $248.1 \pm 3.8 \mathrm{Ma}(\mathrm{MSWD}=3.6, \mathrm{n}=14)$} \\
\hline ZZG11.1 & 0.0516 & 0.0014 & 0.2831 & 0.0082 & 0.0395 & 0.0006 & 333.4 & 60.2 & 253.1 & 6.5 & 249.6 & 3.5 \\
\hline ZZG11.2 & 0.0522 & 0.0017 & 0.2919 & 0.0098 & 0.0409 & 0.0008 & 294.5 & 72.2 & 260.1 & 7.7 & 258.6 & 5.0 \\
\hline ZZG11.4 & 0.0507 & 0.0013 & 0.2639 & 0.0074 & 0.0377 & 0.0005 & 227.8 & 59.3 & 237.8 & 5.9 & 238.6 & 3.0 \\
\hline ZZG11.6 & 0.0518 & 0.0013 & 0.2794 & 0.0076 & 0.0391 & 0.0006 & 276.0 & 63.9 & 250.1 & 6.0 & 247.2 & 3.6 \\
\hline ZZG11.7 & 0.0511 & 0.0015 & 0.2675 & 0.0082 & 0.0382 & 0.0007 & 242.7 & 68.5 & 240.7 & 6.6 & 241.9 & 4.3 \\
\hline ZZG11.8 & 0.0519 & 0.0023 & 0.2946 & 0.0140 & 0.0411 & 0.0007 & 279.7 & 100.0 & 262.2 & 11.0 & 259.5 & 4.2 \\
\hline ZZG11.10 & 0.0535 & 0.0023 & 0.2956 & 0.0131 & 0.0400 & 0.0006 & 350.1 & 96.3 & 263.0 & 10.2 & 252.9 & 3.9 \\
\hline ZZG11.14 & 0.0510 & 0.0013 & 0.2845 & 0.0074 & 0.0404 & 0.0005 & 242.7 & 54.6 & 254.3 & 5.9 & 255.5 & 3.1 \\
\hline ZZG11.15 & 0.0533 & 0.0013 & 0.2925 & 0.0075 & 0.0398 & 0.0005 & 342.7 & 55.6 & 260.5 & 5.9 & 251.4 & 3.1 \\
\hline ZZG11.16 & 0.0532 & 0.0012 & 0.2865 & 0.0065 & 0.0390 & 0.0004 & 338.9 & 50.0 & 255.8 & 5.2 & 246.5 & 2.6 \\
\hline ZZG11.19 & 0.0532 & 0.0012 & 0.2944 & 0.0078 & 0.0401 & 0.0006 & 344.5 & 53.7 & 262.0 & 6.1 & & 3.8 \\
\hline ZZG11.20 & 0.0567 & 0.0012 & 0.2917 & 0.0074 & 0.0374 & 0.0006 & 479.7 & 48.1 & 259.9 & 5.8 & 236.5 & 3.9 \\
\hline ZZG11.21 & 0.0512 & 0.0013 & 0.2750 & 0.0082 & 0.0387 & 0.0005 & 250.1 & 59.3 & 246.7 & 6.5 & 245.0 & 3.2 \\
\hline ZZG11.25 & 0.0597 & 0.0016 & 0.3124 & 0.0081 & 0.0384 & 0.0007 & 590.8 & 58.2 & 276.1 & 6.3 & 242.7 & 4.2 \\
\hline \multicolumn{13}{|c|}{ ZZG11: $222.1 \pm 4.4 \mathrm{Ma}(\mathrm{MSWD}=1.4, \mathrm{n}=5)$} \\
\hline ZZG11.3 & 0.0539 & 0.0013 & 0.2579 & 0.0072 & 0.0344 & 0.0005 & 368.6 & 55.6 & 233.0 & 5.8 & 218.3 & 3.2 \\
\hline ZZG11.5 & 0.0542 & 0.0013 & 0.2669 & 0.0068 & 0.0356 & 0.0004 & 388.9 & 51.8 & 240.2 & 5.5 & 225.3 & 2.7 \\
\hline ZZG11.22 & 0.0563 & 0.0011 & 0.2710 & 0.0059 & 0.0349 & 0.0004 & 464.9 & 44.4 & 243.5 & 4.7 & 221.2 & 2.5 \\
\hline ZZG11.23 & 0.0570 & 0.0015 & 0.2655 & 0.0070 & 0.0342 & 0.0007 & 500.0 & 57.4 & 239.1 & 5.6 & 216.8 & 4.2 \\
\hline ZZG11.24 & 0.0585 & 0.0014 & 0.2853 & 0.0064 & 0.0356 & 0.0005 & 550.0 & 51.8 & 254.8 & 5.1 & 225.3 & 3.0 \\
\hline \multicolumn{13}{|c|}{ ZZG11: $203.5 \pm 2.2 \mathrm{Ma}(\mathrm{n}=1)$} \\
\hline ZZG11.18 & 0.0612 & 0.0014 & 0.2702 & 0.0061 & 0.0321 & 0.0004 & 655.6 & 50.0 & 242.8 & 4.9 & 203.5 & 2.2 \\
\hline \multicolumn{13}{|c|}{ ZZG12: Inherited Zircon } \\
\hline ZZG12.1 & 0.1130 & 0.0025 & 3.6467 & 0.0903 & 0.2312 & 0.0035 & 1850.0 & 39.7 & 1559.8 & 19.8 & 1341.0 & 18.3 \\
\hline ZZG12.2 & 0.1172 & 0.0039 & 5.2503 & 0.1720 & 0.3241 & 0.0053 & 1913.9 & 59.4 & 1860.8 & 28.0 & 1809.9 & 25.8 \\
\hline ZZG12.13 & 0.0601 & 0.0016 & 0.6331 & 0.0193 & 0.0759 & 0.0017 & 609.3 & 59.3 & 498.1 & 12.0 & 471.8 & 10.2 \\
\hline ZZG12.14 & 0.1117 & 0.0026 & 4.6682 & 0.1215 & 0.3003 & 0.0048 & 1827.8 & 42.0 & 1761.6 & 21.8 & 1692.9 & 23.7 \\
\hline \multicolumn{13}{|c|}{ ZZG12: $246.1 \pm 5.2 \mathrm{Ma}(\mathrm{MSWD}=1.8, \mathrm{n}=6)$} \\
\hline ZZG12.3 & 0.0541 & 0.0017 & 0.2895 & 0.0088 & 0.0385 & 0.0005 & 376.0 & 75.0 & 258.2 & 6.9 & 243.3 & 3.3 \\
\hline ZZG12.6 & 0.0522 & 0.0017 & 0.2756 & 0.0091 & 0.0381 & 0.0005 & 294.5 & 74.1 & 247.2 & 7.2 & 241.0 & 3.4 \\
\hline ZZG12.7 & 0.0541 & 0.0021 & 0.2935 & 0.0125 & 0.0391 & 0.0007 & 372.3 & 87.0 & 261.3 & 9.8 & 247.2 & 4.5 \\
\hline ZZG12.9 & 0.0556 & 0.0014 & 0.2948 & 0.0072 & 0.0386 & 0.0005 & 438.9 & 55.6 & 262.3 & 5.6 & 244.1 & 3.3 \\
\hline ZZG12.10 & 0.0521 & 0.0015 & 0.2889 & 0.0087 & 0.0400 & 0.0006 & 300.1 & 60.2 & 257.7 & 6.9 & 252.9 & 3.8 \\
\hline ZZG12.20 & 0.0614 & 0.0022 & 0.3404 & 0.0109 & 0.0399 & 0.0007 & 653.7 & 75.9 & 297.5 & 8.2 & 252.3 & 4.2 \\
\hline \multicolumn{13}{|c|}{ ZZG12: $226.0 \pm 9.1 \mathrm{Ma}(\mathrm{MSWD}=5.6, \mathrm{n}=5)$} \\
\hline ZZG12.4 & 0.0598 & 0.0017 & 0.2910 & 0.0080 & 0.0351 & 0.0005 & 594.5 & 63.0 & 259.3 & 6.3 & 222.6 & 2.9 \\
\hline ZZG12.5 & 0.0578 & 0.0018 & 0.2912 & 0.0081 & 0.0365 & 0.0006 & 524.1 & 68.5 & 259.5 & 6.4 & 231.4 & 3.5 \\
\hline ZZG12.12 & 0.0491 & 0.0016 & 0.2470 & 0.0080 & 0.0364 & 0.0005 & 153.8 & 77.8 & 224.1 & 6.5 & 230.7 & 3.2 \\
\hline
\end{tabular}


Table 1. Cont.

\begin{tabular}{|c|c|c|c|c|c|c|c|c|c|c|c|c|}
\hline \multirow{3}{*}{ Sample No. } & \multicolumn{6}{|c|}{ Isotopic Ratios } & \multicolumn{6}{|c|}{ Ages (Ma) } \\
\hline & \multicolumn{2}{|c|}{${ }^{207} \mathrm{~Pb} /{ }^{206} \mathrm{~Pb}$} & \multicolumn{2}{|c|}{${ }^{207} \mathrm{~Pb} /{ }^{235} \mathrm{U}$} & \multicolumn{2}{|c|}{${ }^{206} \mathrm{~Pb} /{ }^{238} \mathrm{U}$} & \multicolumn{2}{|c|}{${ }^{207} \mathrm{~Pb} /{ }^{206} \mathrm{~Pb}$} & \multicolumn{2}{|c|}{${ }^{207} \mathrm{~Pb} /{ }^{235} \mathrm{U}$} & \multicolumn{2}{|c|}{${ }^{206} \mathrm{~Pb} /{ }^{238} \mathrm{U}$} \\
\hline & Ratio & $1 \sigma$ & Ratio & $1 \sigma$ & Ratio & $1 \sigma$ & Age & $1 \sigma$ & Age & $1 \sigma$ & Age & $1 \sigma$ \\
\hline ZZG12.15 & 0.0624 & 0.0014 & 0.2984 & 0.0063 & 0.0345 & 0.0004 & 687.1 & 52.8 & 265.2 & 4.9 & 218.4 & 2.5 \\
\hline ZZG12.18 & 0.0531 & 0.0018 & 0.2755 & 0.0092 & 0.0374 & 0.0006 & 344.5 & 77.8 & 247.1 & 7.3 & 236.5 & 3.9 \\
\hline \multicolumn{13}{|c|}{ ZZG12: $203.4 \pm 5.2 \mathrm{Ma}(\mathrm{MSWD}=0.12, \mathrm{n}=2)$} \\
\hline ZZG12.8 & 0.0521 & 0.0015 & 0.2301 & 0.0086 & 0.0318 & 0.0008 & 300.1 & 60.2 & 210.3 & 7.1 & 201.8 & 5.2 \\
\hline ZZG12.16 & 0.0576 & 0.0019 & 0.2569 & 0.0078 & 0.0321 & 0.0005 & 522.3 & 70.4 & 232.2 & 6.3 & 204.0 & 3.1 \\
\hline
\end{tabular}

\subsection{Zircon Trace Element Composition and Oxygen Fugacity}

Trace element compositions of zircons from sample ZZG11 and ZZG12 are listed in Table 2. The chondrite-normalized REE patterns are illustrated in Figure 8. The inherited zircons show strong positive $\mathrm{Ce}\left(\mathrm{Ce} / \mathrm{Ce} e^{*}\right.$ ratios, where $\left.\mathrm{Ce}^{*}=\sqrt{(\mathrm{La})_{\mathrm{N}} \times(\mathrm{Pr})_{\mathrm{N}}}\right)$ and negative $\mathrm{Eu}\left(\mathrm{Eu} / \mathrm{Eu}^{*}\right.$ ratios, where $\left.\mathrm{Eu}^{*}=\sqrt{(\mathrm{Sm})_{\mathrm{N}} \times(\mathrm{Gd})_{\mathrm{N}}}\right)$ anomalies, ranging from 2.48 to 394.68 , and 0.02 to 0.43 , respectively. The $\sim 248-246 \mathrm{Ma}$ and $\sim 226-222 \mathrm{Ma}$ zircons show moderate positive Ce and negative Eu anomalies. The $\mathrm{Ce} / \mathrm{Ce}^{*}$ and $\mathrm{Eu} / \mathrm{Eu}^{*}$ of $\sim 248-246 \mathrm{Ma}$ zircons vary from 1.31 to 61.75 and 0.18 to 0.62 , respectively. The $\mathrm{Ce} / \mathrm{Ce}^{*}$ and $\mathrm{Eu} / \mathrm{Eu}^{*}$ of $\sim 226-222 \mathrm{Ma}$ zircons vary from 1.24 to 4.90 , and 0.46 to 0.63 , respectively. The 203 Ma zircons have high REE contents and weak positive $\mathrm{Ce}\left(\mathrm{Ce} / \mathrm{Ce}^{*}=1.48\right.$ to 4.37$)$ and negative $\mathrm{Eu}$ anomalies $\left(\mathrm{Eu} / \mathrm{Eu}^{*}=0.44\right.$ to 0.73$)$.
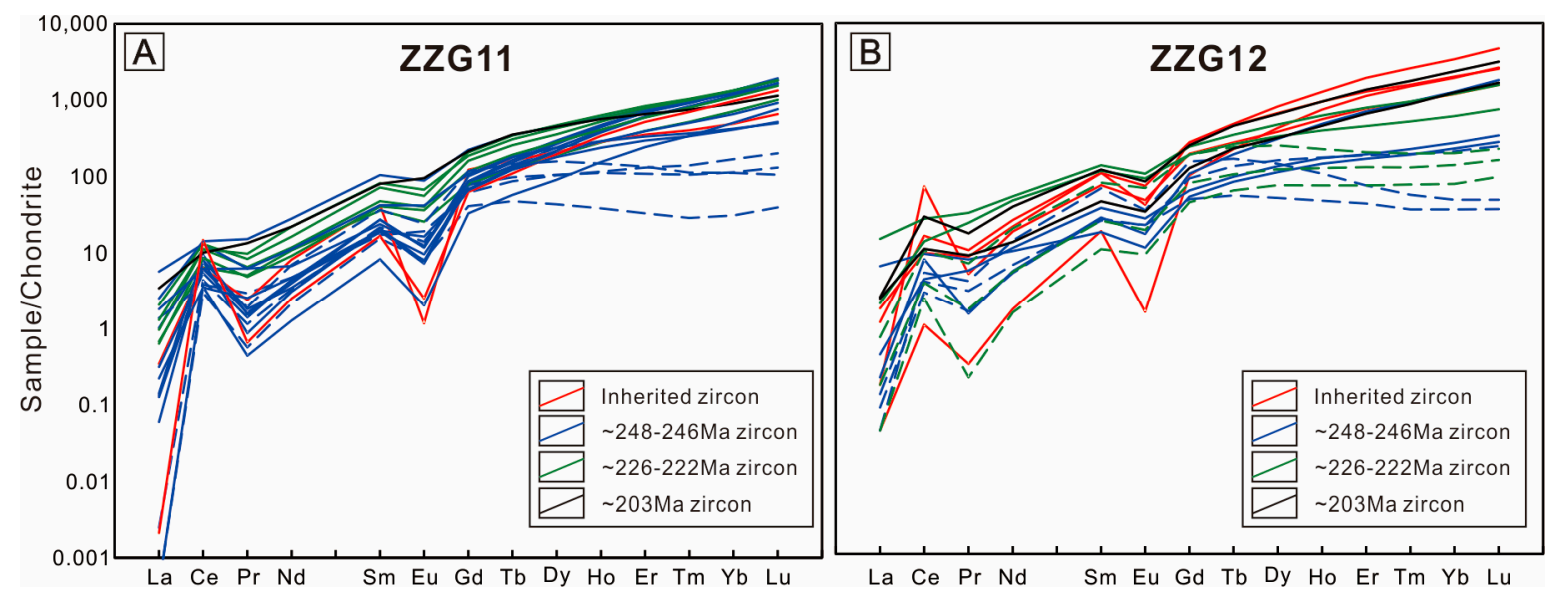

Figure 8. Chondrite-normalized REE patterns for ZZG11 (A) and ZZG12 (B). Note the HREE value anomalies (dashed lines) which may be indicative of contamination by inclusions or alteration.

The zircon crystallization temperatures and oxygen fugacities were calculated and listed in Table 2 and Figure 9. Aberrant REE values (dashed lines in Figure 8) which may be indicative of contamination by inclusions or alteration are excluded from the calculation (Figure 6). The logarithmic oxygen fugacities $\left(\mathrm{fO}_{2}\right)$ of the inherited zircons range from -10.58 to -1.39 , with $\triangle \mathrm{FMQ}$ ranging from -6.13 to 2.93. The logarithmic oxygen fugacities of the $248-246 \mathrm{Ma}$ zircons range from -9.17 to -7.16 , with $\triangle \mathrm{FMQ}$ ranging from -4.61 to -2.56 . The logarithmic oxygen fugacities of the $\sim 226-222 \mathrm{Ma}$ zircons range from -8.08 to -6.09 , with $\triangle \mathrm{FMQ}$ ranging from -3.52 to -1.48 . The logarithmic oxygen fugacities of the $\sim 203$ Ma zircons range from -7.99 to -6.45 , with $\Delta \mathrm{FMQ}$ ranging from -3.47 to -1.74 . 

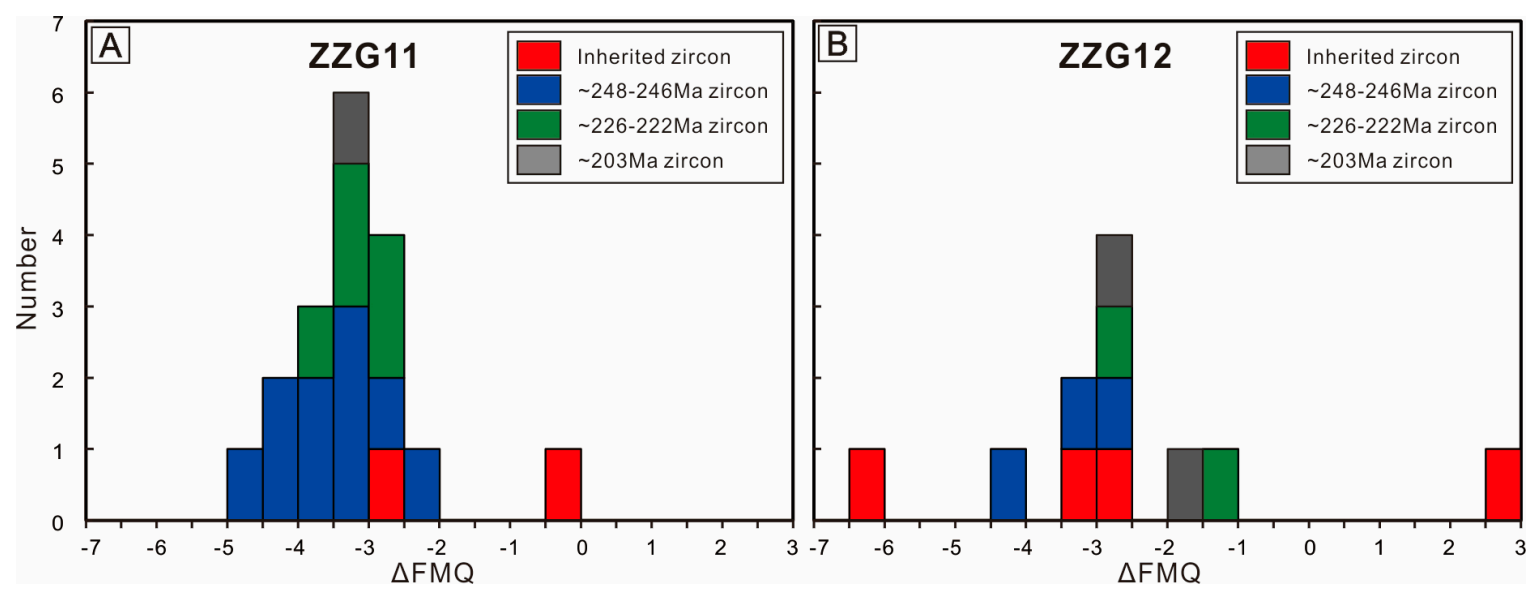

Figure 9. Magma oxygen fugacity for ZZG11 (A) and ZZG12 (B).

\subsection{Zircon Lu-Hf Isotopic Composition}

In situ zircon Lu-Hf isotopic data of magmatic zircons and inherited zircons are presented in Table 3 and shown in Figure 10. The single stage depleted-mantle model ages $\left(\mathrm{T}_{\mathrm{DM}}{ }^{1}\right)$ are determined for each sample by calculating the intersection of the zircon/parent-rock growth trajectory with the depleted-mantle evolution curve $[6,9,35]$. The two-stage model ages $\left(\mathrm{T}_{\mathrm{DM}^{2}}\right)^{2}$ are calculated for the source rock of the magma by assuming a mean ${ }^{176} \mathrm{Lu} /{ }^{177} \mathrm{Hf}$ value of 0.015 for an average continental crust [6]. For sample ZZG11, the 14 magmatic zircon grains yield ${ }^{176} \mathrm{Lu} /{ }^{177} \mathrm{Hf}$ and ${ }^{176} \mathrm{Hf} /{ }^{177} \mathrm{Hf}$ ratios of $0.000031-0.000718$ and $0.282263-0.282361$, respectively. They show negative $\varepsilon_{\mathrm{Hf}}(\mathrm{t})$ values (age corrected using $\mathrm{U}-\mathrm{Pb}$ age for individual grains) in the range of -12.5 to -9.3 , falling below the CHUR (chondrite uniform reservoir) line (Figure 10A,B). The corresponding calculated $\mathrm{T}_{\mathrm{DM}^{2}}{ }^{2}$ values range from 1.86 to $2.08 \mathrm{Ga}$ (Figure 10D). The Paleoproterozoic inherited zircons have ${ }^{176} \mathrm{Lu} /{ }^{177} \mathrm{Hf}$ ratio of 0.000424 and $0.000560,{ }^{176} \mathrm{Hf} /{ }^{177} \mathrm{Hf}$ ratios of 0.281747 and 0.281540 , and $\varepsilon_{\mathrm{Hf}}(\mathrm{t})$ value of 2.4 and -6.1 , with corresponding $\mathrm{T}_{\mathrm{DM}}{ }^{2}$ of 2.28 and $2.78 \mathrm{Ga}$. For sample ZZG12, the six magmatic zircon grains have ${ }^{176} \mathrm{Lu} /{ }^{177} \mathrm{Hf}$ ratio of 0.000012 to $0.000542,{ }^{176} \mathrm{Hf} /{ }^{177} \mathrm{Hf}$ ratios of 0.282323 to 0.282371 , and negative $\varepsilon_{\mathrm{Hf}}(\mathrm{t})$ value of -10.9 to -8.9 , falling below the CHUR line (Figure 10A,B), with corresponding $\mathrm{T}_{\mathrm{DM}^{2}}{ }^{2}$ of 1.97 to $1.84 \mathrm{Ga}$ (Figure 10D). The $471.8 \mathrm{Ma}$ zircon yielding negative $\varepsilon_{\mathrm{Hf}}(\mathrm{t})$ values of -8.8 have corresponding $\mathrm{T}_{\mathrm{DM}^{2}}$ of $1.43 \mathrm{Ga}$. The Proterozoic inherited zircons have $\varepsilon_{\mathrm{Hf}}(\mathrm{t})$ values of $2.5,-8.9,-5.2$, with corresponding $\mathrm{T}_{\mathrm{DM}}{ }^{2}$ of $2.02,2.16$, and $2.42 \mathrm{Ga}$. 

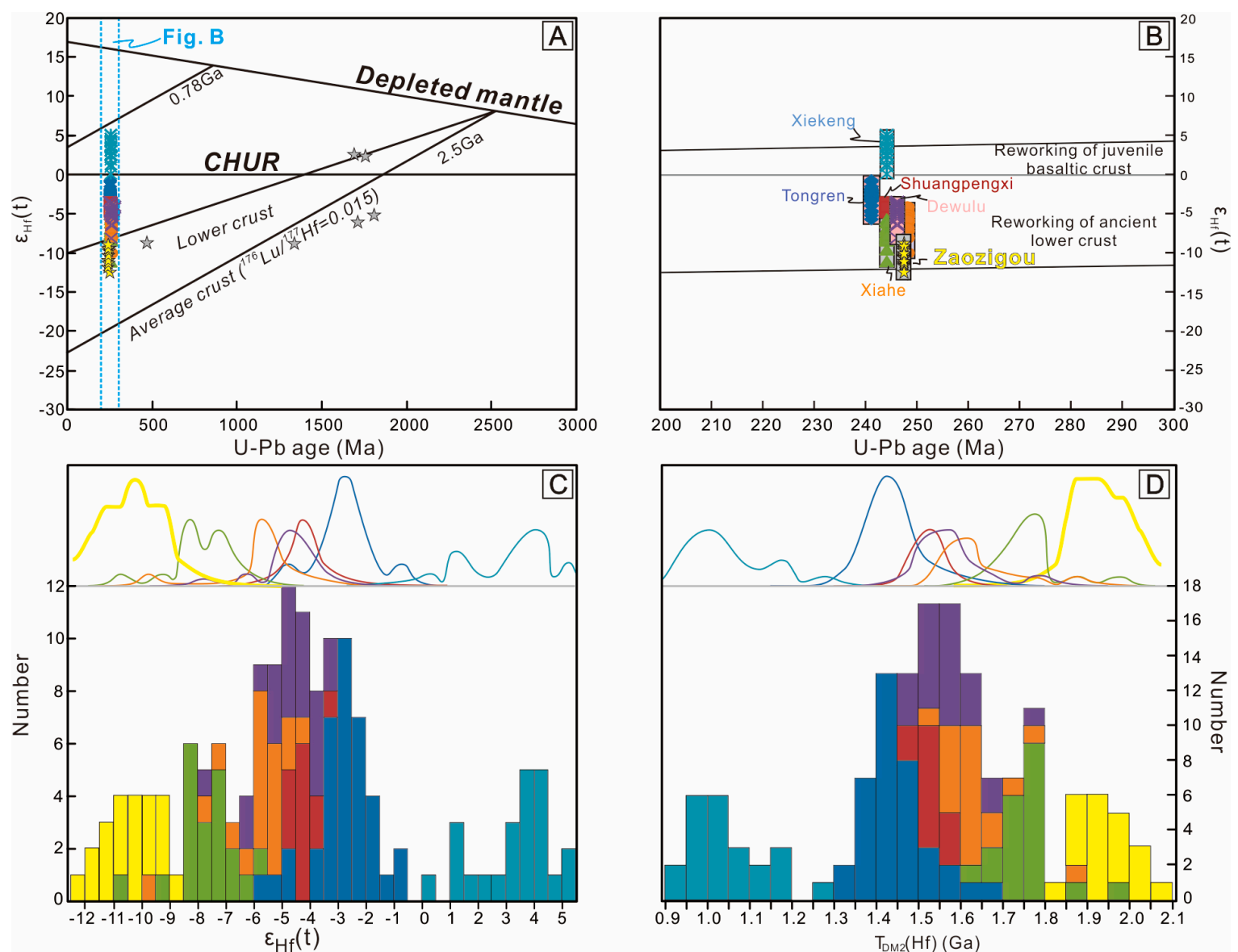

Sample in this study:

is. $\square$ Zaozigou dacite porphyry $247 \mathrm{Ma}(\mathrm{n}=20)$

Data from literature:

W Xiekeng gandioitic pophyry 244Ma (n=23)

Zaozigou inherited zircon $(n=6)$

$\square$ Xiahe granodiorite 248Ma $(n=19) \quad \triangle \square$ Xiahe granodiorite $244 \mathrm{Ma}(\mathrm{n}=20)$ 作

Figure 10. Variations of $\varepsilon_{\mathrm{Hf}}(\mathrm{t})$ values versus $\mathrm{U}-\mathrm{Pb}$ ages $(\mathrm{Ma})$ of zircons from the Triassic granitoids in the Tongren-Xiahe-Hezuo area (A,B). (C) Histograms, and frequency curves of $\varepsilon_{\mathrm{Hf}}(\mathrm{t})$ values. (D) Histograms, and frequency curves of corresponding two-stage $\mathrm{Hf}$ model ages $\left(\mathrm{T}_{\mathrm{DM}}{ }^{2}\right)$ (modified after [6]). 
Table 2. Trace element concentration, and calculated Ti-in-zircon temperatures ( $\mathrm{T})$, logarithmic oxygen fugacity $\left(\operatorname{logfO} \mathrm{O}_{2}\right)$, and $\Delta \mathrm{FMQ}$ of zircons from the porphyritic dacite samples ZZG11 and ZZG12.

\begin{tabular}{|c|c|c|c|c|c|c|c|c|c|c|c|c|c|c|c|c|c|c|c|c|c|c|c|c|}
\hline Spot No. & $\mathrm{Ti}$ & $\mathbf{Y}$ & La & $\mathrm{Ce}$ & Pr & Nd & Sm & Eu & Gd & $\mathrm{Tb}$ & Dy & Ho & Er & $\mathrm{Tm}$ & $\mathbf{Y b}$ & Lu & Hf & Th & $\mathbf{U}$ & $\delta \mathrm{Eu}$ & $\delta \mathrm{Ce}$ & $\mathbf{T}(\mathbf{K})$ & $\operatorname{logfO} O_{2}$ & $\Delta \mathrm{FMQ}$ \\
\hline \multicolumn{25}{|c|}{ ZZG11: Inherited Zircon } \\
\hline ZZG11.9 & 1088 & 464 & 0.08 & 3.91 & 0.23 & 3.85 & 6.52 & 0.07 & 25.5 & 6.11 & 53.7 & 16.2 & 59 & 10.3 & 84 & 16.8 & 10127 & 158 & 308 & 0.02 & 6.97 & 1957 & -6.80 & -2.87 \\
\hline ZZG11.11 & 916 & 564 & 0.00 & 9.07 & 0.06 & 1.18 & 2.57 & 0.15 & 13.1 & 4.15 & 50.4 & 19.4 & 86 & 18.0 & 167 & 34.2 & 10067 & 33 & 245 & 0.08 & 394.68 & 1899 & -4.78 & -0.41 \\
\hline \multicolumn{25}{|c|}{ ZZG11: $248.1 \pm 3.8 \mathrm{Ma}(\mathrm{MSWD}=3.6, \mathrm{n}=14)$} \\
\hline ZZG11.1 & 867 & 714 & 0.24 & 4.93 & 0.17 & 1.64 & 2.98 & 0.42 & 15.8 & 5.23 & 61.7 & 22.7 & 102 & 21.1 & 196 & 42.2 & 9432 & 156 & 2962 & 0.19 & 5.88 & 1882 & -7.78 & -3.27 \\
\hline ZZG11.2* & 898 & 207 & 0.00 & 2.68 & 0.11 & 1.57 & 3.33 & 0.83 & 16.2 & 3.69 & 26.9 & 6.4 & 18 & 2.7 & 20 & 3.4 & 10066 & 118 & 1671 & 0.34 & 81.61 & - & - & - \\
\hline ZZG11.4* & 899 & 280 & 0.03 & 3.87 & 0.19 & 3.29 & 5.63 & 1.42 & 24.6 & 5.47 & 40.4 & 8.4 & 23 & 2.9 & 19 & 2.7 & 7966 & 174 & 2023 & 0.37 & 12.36 & - & - & - \\
\hline ZZG11.6 & 850 & 439 & 0.05 & 2.17 & 0.24 & 2.22 & 3.01 & 0.96 & 13.8 & 4.62 & 46.0 & 13.7 & 49 & 8.7 & 71 & 13.4 & 10943 & 49 & 3061 & 0.46 & 4.68 & 1875 & -9.17 & -4.61 \\
\hline ZZG11.7 * & 861 & 220 & 0.33 & 2.35 & 0.28 & 2.24 & 2.64 & 1.12 & 12.8 & 3.26 & 26.7 & 6.6 & 22 & 3.6 & 29 & 5.2 & 10818 & 47 & 2023 & 0.59 & 1.90 & - & - & - \\
\hline ZZG11.8* & 823 & 73 & 0.00 & 1.85 & 0.05 & 1.01 & 2.40 & 0.47 & 8.5 & 1.79 & 11.1 & 2.2 & 6 & 0.7 & 5 & 1.0 & 9292 & 53 & 1118 & 0.32 & 61.75 & - & - & - \\
\hline ZZG11.10 & 871 & 282 & 0.00 & 2.21 & 0.04 & 0.60 & 1.27 & 0.12 & 6.9 & 2.17 & 23.2 & 8.9 & 40 & 8.8 & 86 & 19.6 & 11239 & 76 & 2031 & 0.12 & 83.58 & 1883 & -8.88 & -4.38 \\
\hline ZZG11.14 & 785 & 805 & 1.35 & 8.10 & 0.60 & 3.18 & 3.66 & 0.74 & 18.0 & 6.21 & 70.2 & 25.5 & 116 & 23.5 & 217 & 46.8 & 8666 & 183 & 3410 & 0.28 & 2.21 & 1850 & -7.18 & -2.42 \\
\hline ZZG11.15 & 874 & 514 & 0.07 & 3.34 & 0.14 & 2.09 & 4.19 & 0.69 & 17.8 & 5.07 & 51.9 & 16.5 & 66 & 12.9 & 113 & 23.6 & 9989 & 115 & 2672 & 0.24 & 8.16 & 1884 & -8.37 & -3.88 \\
\hline ZZG11.16 & 853 & 830 & 0.03 & 5.79 & 0.15 & 1.88 & 4.23 & 0.69 & 20.9 & 6.71 & 76.0 & 27.0 & 118 & 24.4 & 220 & 46.7 & 9246 & 264 & 3854 & 0.22 & 20.10 & 1876 & -7.84 & -3.28 \\
\hline ZZG11.19 & 811 & 797 & 0.01 & 4.81 & 0.08 & 1.46 & 3.22 & 0.46 & 17.9 & 5.75 & 68.1 & 25.6 & 114 & 23.9 & 227 & 49.6 & 8941 & 192 & 3348 & 0.18 & 34.23 & 1860 & -8.05 & -3.37 \\
\hline ZZG11.20 & 839 & 1033 & 0.60 & 8.81 & 1.45 & 13.33 & 16.15 & 5.17 & 46.2 & 13.15 & 118.0 & 33.6 & 12 & 24.3 & 208 & 41.6 & 9156 & 197 & 3884 & 0.58 & 2.32 & 1871 & -7.16 & -2.56 \\
\hline ZZG11.21 & 863 & 667 & 0.03 & 3.83 & 0.16 & 2.03 & 2.88 & 0.56 & 14.2 & 4.83 & 56.2 & 21.6 & 100 & 21.3 & 198 & 42.9 & 8769 & 126 & 2609 & 0.27 & 13.70 & 1880 & -8.03 & -3.51 \\
\hline ZZG11.25 & 871 & 523 & 0.43 & 3.83 & 0.59 & 5.29 & 6.50 & 2.43 & 22.4 & 6.79 & 61.1 & 16.6 & 56 & 9.5 & 72 & 12.9 & 10407 & 66 & 3051 & 0.62 & 1.85 & 1883 & -8.57 & -4.07 \\
\hline \multicolumn{25}{|c|}{ ZZG11: $222.1 \pm 4.4 \mathrm{Ma}(\mathrm{MSWD}=1.4, \mathrm{n}=5)$} \\
\hline ZZG11.3 & 910 & 960 & 0.23 & 6.96 & 0.63 & 5.53 & 7.37 & 2.36 & 33.5 & 9.73 & 91.4 & 29.8 & 123 & 25.1 & 229 & 47.3 & 10302 & 213 & 4279 & 0.46 & 4.49 & 1897 & -7.49 & -3.10 \\
\hline ZZG11.5 & 851 & 496 & 0.16 & 4.01 & 0.49 & 5.10 & 5.57 & 1.51 & 16. & 4.89 & 49.0 & 16.0 & 66 & 13.4 & 123 & 25.9 & 10402 & 105 & 2595 & 0.48 & 3.50 & 1876 & -8.08 & -3.52 \\
\hline ZZG11.22 & 859 & 1139 & 0.49 & 8.03 & 0.80 & 7.71 & 11.12 & 3.25 & 42.8 & 12.98 & 119.9 & 36.2 & 140 & 26.8 & 230 & 46.8 & 9615 & 222 & 3925 & 0.46 & 3.14 & 1879 & -7.31 & -2.77 \\
\hline ZZG11.23 & 835 & 1027 & 0.31 & 6.93 & 0.94 & 10.39 & 12.67 & 3.93 & 38.9 & 11.59 & 110.1 & 33.2 & 131 & 25.7 & 228 & 46.4 & 9428 & 204 & 4037 & 0.54 & 3.15 & 1870 & -7.58 & -2.98 \\
\hline ZZG11.24 & 837 & 744 & 0.15 & 5.28 & 0.46 & 4.29 & 6.27 & 2.13 & 24.2 & 7.24 & 72.4 & 23.4 & 98 & 20.5 & 189 & 39.4 & 10041 & 168 & 3368 & 0.53 & 4.90 & 1870 & -7.90 & -3.30 \\
\hline \multicolumn{25}{|c|}{ ZZG11: $203.5 \pm 2.2 \mathrm{Ma}(\mathrm{n}=1)$} \\
\hline ZZG11.18 & 863 & 1002 & 0.81 & 6.18 & 1.28 & 10.39 & 12.47 & 5.59 & 44.5 & 13.36 & 115.6 & 32.2 & 110 & 19.3 & 155 & 29.3 & 11251 & 59 & 4979 & 0.73 & 1.48 & 1880 & -7.99 & -3.47 \\
\hline \multicolumn{25}{|c|}{ ZZG12: Inherited Zircon } \\
\hline ZZG12.1 & 877 & 1508 & 0.27 & 9.66 & 0.97 & 11.88 & 16.37 & 2.35 & 54.4 & 16.81 & 166.8 & 52.5 & 207 & 39.3 & 336 & 63.3 & 9976 & 396 & 3372 & 0.24 & 4.66 & 1885 & -7.06 & -2.58 \\
\hline ZZG12.2 & 933 & 882 & 0.04 & 43.27 & 0.47 & 8.38 & 11.27 & 2.70 & 39.1 & 9.96 & 94.5 & 30.6 & 123 & 23.4 & 197 & 39.2 & 8268 & 42 & 94 & 0.39 & 73.75 & 1905 & -1.39 & 2.93 \\
\hline ZZG12.13 & 803 & 2000 & 0.41 & 5.76 & 0.80 & 9.75 & 16.18 & 4.19 & 55.6 & 17.63 & 203.0 & 70.0 & 315 & 64.6 & 567 & 117.5 & 10164 & 210 & 2990 & 0.43 & 2.48 & 1857 & -7.85 & -3.15 \\
\hline ZZG12.14 & 889 & 1225 & 0.01 & 0.64 & 0.03 & 0.79 & 2.78 & 0.09 & 20.4 & 8.22 & 105.6 & 40.9 & 182 & 37.5 & 324 & 66.0 & 11673 & 37 & 1328 & 0.04 & 10.59 & 1890 & -10.58 & -6.13 \\
\hline
\end{tabular}


Table 2. Cont.

\begin{tabular}{|c|c|c|c|c|c|c|c|c|c|c|c|c|c|c|c|c|c|c|c|c|c|c|c|c|}
\hline Spot No. & Ti & $\mathbf{Y}$ & La & Ce & Pr & Nd & Sm & Eu & Gd & $\mathrm{Tb}$ & Dy & Ho & Er & $\operatorname{Tm}$ & $\mathrm{Yb}$ & Lu & Hf & Th & $\mathbf{U}$ & $\delta$ Eu & $\delta \mathrm{Ce}$ & $\mathbf{T}(\mathbf{K})$ & $\operatorname{logfO} \mathrm{O}_{2}$ & $\Delta \mathrm{FMQ}$ \\
\hline \multicolumn{25}{|c|}{ ZZG12: $246.1 \pm 5.2 \mathrm{Ma}(\mathrm{MSWD}=1.8, \mathrm{n}=6)$} \\
\hline ZZG12.3 & 834 & 290 & 0.10 & 2.59 & 0.52 & 5.12 & 5.67 & 1.55 & 12.9 & 3.54 & 33.2 & 9.4 & 31 & 5.6 & 45 & 8.4 & 10779 & 43 & 2614 & 0.55 & 2.72 & 1869 & -8.89 & -4.28 \\
\hline ZZG12.6* & 862 & 77 & 0.03 & 2.40 & 0.28 & 3.04 & 3.83 & 1.28 & 9.9 & 2.02 & 12.7 & 2.6 & 7 & 0.9 & 6 & 0.9 & 9121 & 103 & 1170 & 0.64 & 6.12 & - & - & - \\
\hline ZZG12.7* & 872 & 188 & 0.01 & 3.14 & 0.38 & 6.38 & 10.22 & 2.00 & 31.0 & 6.11 & 35.9 & 5.9 & 12 & 1.4 & 8 & 1.2 & 7997 & 94 & 989 & 0.34 & 14.85 & - & - & - \\
\hline ZZG12.9 & 844 & 248 & 1.49 & 5.59 & 0.73 & 4.63 & 2.70 & 0.64 & 10.6 & 3.06 & 27.7 & 8.0 & 27 & 4.7 & 38 & 6.9 & 11025 & 38 & 2051 & 0.37 & 1.31 & 1873 & -7.2 & -2.62 \\
\hline ZZG12.10* & 861 & 314 & 0.02 & 1.73 & 0.15 & 2.38 & 4.06 & 1.25 & 18.6 & 4.87 & 39.7 & 9.6 & 30 & 4.8 & 35 & 6.1 & 10190 & 61 & 2604 & 0.44 & 7.01 & - & - & - \\
\hline ZZG12.20 & 840 & 812 & 0.05 & 4.73 & 0.14 & 2.51 & 4.22 & 0.97 & 21.3 & 6.95 & 75.8 & 26.7 & 113 & 23.5 & 212 & 45.3 & 8990 & 154 & 2930 & 0.31 & 13.05 & 1871 & -7.87 & -3.28 \\
\hline \multicolumn{25}{|c|}{ ZZG12: $226.0 \pm 9.1 \mathrm{Ma}(\mathrm{MSWD}=5.6, \mathrm{n}=5)$} \\
\hline ZZG12.4 & 771 & 672 & 0.48 & 8.16 & 2.24 & 21.62 & 17.29 & 5.25 & 38.0 & 9.49 & 82.1 & 21.8 & 73 & 12.9 & 101 & 18.6 & 9658 & 79 & 3721 & 0.63 & 1.94 & 1845 & -7.6 & -2.8 \\
\hline ZZG12.5* & 828 & 380 & 0.17 & 6.15 & 0.65 & 9.21 & 12.12 & 3.91 & 37.9 & 8.77 & 62.5 & 12.4 & 33 & 4.9 & 33 & 5.6 & 9227 & 256 & 3070 & 0.56 & 4.52 & - & - & - \\
\hline ZZG12.12* & 876 & 132 & 0.01 & 1.42 & 0.02 & 0.71 & 1.61 & 0.52 & 9.0 & 2.35 & 18.7 & 4.1 & 12 & 1.9 & 13 & 2.4 & 10659 & 52 & 1502 & 0.42 & 25.21 & - & - & - \\
\hline ZZG12.15 & 835 & 1064 & 3.41 & 16.16 & 3.01 & 24.46 & 20.45 & 6.02 & 48.7 & 12.61 & 117.2 & 34.4 & 127 & 23.6 & 200 & 38.8 & 10722 & 75 & 5414 & 0.58 & 1.24 & 1870 & -6.09 & -1.48 \\
\hline ZZG12.18* & 885 & 223 & 0.04 & 2.30 & 0.16 & 2.47 & 3.85 & 1.10 & 16.1 & 3.83 & 30.1 & 7.0 & 21 & 3.2 & 23 & 4.0 & 10274 & 68 & 1985 & 0.43 & 7.18 & - & - & - \\
\hline \multicolumn{25}{|c|}{ ZZG12: $203.4 \pm 5.2 \mathrm{Ma}(\mathrm{MSWD}=0.12, \mathrm{n}=2)$} \\
\hline ZZG12.8 & 803 & 1532 & 0.58 & 17.32 & 1.62 & 17.87 & 18.07 & 4.78 & 50.4 & 16.62 & 161.1 & 52.6 & 219 & 43.9 & 393 & 78.8 & 10678 & 356 & 5174 & 0.48 & 4.37 & 1857 & -6.45 & -1.74 \\
\hline ZZG12.16 & 853 & 770 & 0.55 & 6.50 & 0.83 & 6.13 & 6.87 & 1.91 & 25.3 & 8.38 & 78.0 & 25.2 & 106 & 22.0 & 207 & 41.6 & 9977 & 99 & 3522 & 0.44 & 2.36 & 1876 & -7.35 & -2.8 \\
\hline
\end{tabular}

Note the data marked with * are indicative of contamination by inclusions or alteration.

Table 3. Zircon Lu-Hf isotopic composition of the porphyritic dacite samples ZZG11 and ZZG12.

\begin{tabular}{|c|c|c|c|c|c|c|c|c|c|c|c|c|}
\hline Sample No. & Age (Ma) & ${ }^{176} \mathrm{Yb} /{ }^{177} \mathrm{Hf}$ & $2 \sigma$ & ${ }^{176} \mathrm{Lu} /{ }^{177} \mathrm{Hf}$ & $2 \sigma$ & ${ }^{176} \mathrm{Hf} /{ }^{177} \mathrm{Hf}$ & $2 \sigma$ & $\varepsilon_{\mathrm{Hf}}(0)$ & $\mathcal{E}_{\mathrm{Hf}}(\mathbf{t})$ & $\mathrm{T}_{\mathrm{DM} 1}(\mathrm{Ma})$ & $\mathrm{T}_{\mathrm{DM} 2}(\mathrm{Ma})$ & $f_{L u / H f}$ \\
\hline \multicolumn{13}{|c|}{ ZZG11: $248.1 \pm 3.8 \mathrm{Ma}$} \\
\hline ZZG11.1 & 249.6 & 0.024139 & 0.000326 & 0.000718 & 0.000008 & 0.282352 & 0.000018 & -14.863592 & -9.508981 & 1263.225048 & 1881.889668 & -0.978380 \\
\hline ZZG11.2 & 258.6 & 0.001701 & 0.000022 & 0.000041 & 0.000001 & 0.282349 & 0.000018 & -14.970353 & -9.307346 & 1245.319464 & 1876.124379 & -0.998762 \\
\hline ZZG11.4 & 238.6 & 0.001524 & 0.000016 & 0.000038 & 0.000001 & 0.282361 & 0.000019 & -14.536947 & -9.302832 & 1228.484312 & 1861.157809 & -0.998852 \\
\hline ZZG11.6 & 247.2 & 0.001250 & 0.000048 & 0.000031 & 0.000001 & 0.282295 & 0.000016 & -16.874484 & -11.460123 & 1318.467147 & 2003.743246 & -0.999062 \\
\hline ZZG11.7 & 241.9 & 0.013728 & 0.000178 & 0.000350 & 0.000003 & 0.282298 & 0.000017 & -16.754266 & -11.507066 & 1324.692857 & 2002.602403 & -0.989470 \\
\hline ZZG11.8 & 259.5 & 0.001559 & 0.000108 & 0.000040 & 0.000002 & 0.282322 & 0.000018 & -15.912184 & -10.229071 & 1281.640849 & 1935.121937 & -0.998798 \\
\hline ZZG11.10 & 252.9 & 0.009459 & 0.000060 & 0.000385 & 0.000002 & 0.282299 & 0.000025 & -16.713617 & -11.233104 & 1324.326437 & 1993.505528 & -0.988407 \\
\hline ZZG11.14 & 255.5 & 0.021607 & 0.000541 & 0.000672 & 0.000017 & 0.282339 & 0.000021 & -15.326172 & -9.836895 & 1279.869410 & 1907.082223 & -0.979755 \\
\hline ZZG11.15 & 251.4 & 0.004712 & 0.000219 & 0.000148 & 0.000006 & 0.282323 & 0.000017 & -15.863755 & -10.375831 & 1283.328974 & 1938.305577 & -0.995557 \\
\hline ZZG11.16 & 246.5 & 0.018488 & 0.000432 & 0.000600 & 0.000012 & 0.282351 & 0.000021 & -14.896557 & -9.589016 & 1260.630563 & 1884.689690 & -0.981924 \\
\hline ZZG11.19 & 253.7 & 0.019748 & 0.000071 & 0.000660 & 0.000005 & 0.282263 & 0.000024 & -17.988048 & -12.538169 & 1383.774218 & 2076.338657 & -0.980125 \\
\hline
\end{tabular}


Table 3. Cont.

\begin{tabular}{|c|c|c|c|c|c|c|c|c|c|c|c|c|}
\hline Sample No. & Age (Ma) & ${ }^{176} \mathrm{Yb} /{ }^{177} \mathrm{Hf}$ & $2 \sigma$ & ${ }^{176} \mathrm{Lu} /{ }^{177} \mathrm{Hf}$ & $2 \sigma$ & ${ }^{176} \mathrm{Hf} /{ }^{177} \mathrm{Hf}$ & $2 \sigma$ & $\varepsilon_{\mathrm{Hf}}(0)$ & $\varepsilon_{\mathrm{Hf}}(t)$ & $\mathrm{T}_{\mathrm{DM} 1}(\mathrm{Ma})$ & $\mathrm{T}_{\mathrm{DM} 2}(\mathrm{Ma})$ & $\mathbf{f}_{\mathrm{Lu} / \mathrm{Hf}}$ \\
\hline ZZG11.20 & 236.5 & 0.019013 & 0.000292 & 0.000550 & 0.000006 & 0.282327 & 0.000019 & -15.719942 & -10.621397 & 1291.189494 & 1942.480958 & -0.983433 \\
\hline ZZG11.21 & 245.0 & 0.019872 & 0.000146 & 0.000662 & 0.000003 & 0.282307 & 0.000024 & -16.457244 & -11.193214 & 1323.873187 & 1984.942448 & -0.980068 \\
\hline ZZG11.25 & 242.7 & 0.008005 & 0.000139 & 0.000217 & 0.000003 & 0.282292 & 0.000018 & -16.992240 & -11.706242 & 1329.367364 & 2015.854097 & -0.993465 \\
\hline \multicolumn{13}{|c|}{ ZZG11: Inherited Zircons } \\
\hline ZZG11.9 & 1759.2 & 0.012876 & 0.000283 & 0.000424 & 0.000009 & 0.281747 & 0.000022 & -36.261673 & 2.407467 & 2081.737912 & 2282.631032 & -0.987219 \\
\hline ZZG11.11 & 1713.2 & 0.019195 & 0.000190 & 0.000560 & 0.000003 & 0.281540 & 0.000022 & -43.572856 & -6.121060 & 2370.087031 & 2775.472413 & -0.983128 \\
\hline \multicolumn{13}{|c|}{ ZZG12: $246.1 \pm 5.2 \mathrm{Ma}$} \\
\hline ZZG12.3 & 243.3 & 0.000531 & 0.000008 & 0.000012 & 0.000000 & 0.282320 & 0.000019 & -15.993589 & -10.661623 & 1283.860523 & 1950.351280 & -0.999637 \\
\hline ZZG12.6 & 241.0 & 0.001371 & 0.000036 & 0.000028 & 0.000001 & 0.282371 & 0.000017 & -14.185466 & -8.905572 & 1214.577203 & 1837.515937 & -0.999168 \\
\hline ZZG12.7 & 247.2 & 0.000853 & 0.000011 & 0.000018 & 0.000000 & 0.282312 & 0.000016 & -16.273862 & -10.857290 & 1294.862014 & 1965.639935 & -0.999462 \\
\hline ZZG12.9 & 244.1 & 0.000518 & 0.000009 & 0.000013 & 0.000000 & 0.282333 & 0.000016 & -15.533076 & -10.183396 & 1266.122384 & 1920.708045 & -0.999616 \\
\hline ZZG12.10 & 252.9 & 0.006756 & 0.000341 & 0.000167 & 0.000008 & 0.282354 & 0.000020 & -14.788333 & -9.270597 & 1242.315778 & 1869.501545 & -0.994974 \\
\hline ZZG12.20 & 252.3 & 0.018541 & 0.000319 & 0.000542 & 0.000007 & 0.282323 & 0.000016 & -15.877285 & -10.442352 & 1297.065034 & 1942.779033 & -0.983679 \\
\hline \multicolumn{13}{|c|}{ ZZG12: Inherited Zircons } \\
\hline ZZG12.1 & 1341.0 & 0.030050 & 0.001042 & 0.000808 & 0.000033 & 0.281702 & 0.000031 & -37.845812 & -8.861764 & 2163.964101 & 2663.095171 & -0.975669 \\
\hline ZZG12.2 & 1809.9 & 0.019174 & 0.000179 & 0.000569 & 0.000003 & 0.281504 & 0.000027 & -44.830641 & -5.235327 & 2418.849006 & 2794.388577 & -0.982856 \\
\hline ZZG12.13 & 471.8 & 0.031474 & 0.000291 & 0.001039 & 0.000012 & 0.282240 & 0.000019 & -18.804106 & -8.761496 & 1429.898743 & 2001.515941 & -0.968699 \\
\hline ZZG12.14 & 1692.9 & 0.015942 & 0.000239 & 0.000436 & 0.000004 & 0.281792 & 0.000028 & -34.661773 & 2.513847 & 2020.856289 & 2224.977230 & -0.986874 \\
\hline
\end{tabular}




\section{Discussion}

\subsection{Triassic Magmatism in Tongren-Xiahe-Hezuo Area}

Several detailed field observations and geochronological studies have been carried out on extensive pulse of Triassic magmatism in the Tongren-Xiahe-Hezuo area. As shown in Figure 1B, Jin et al. [44] preliminarily reported ages of Xiahe, Daerzang, and Yeliguan granitoids at 243-250 Ma, 234-242 Ma, and 237-251 Ma. Luo et al. [14] reported ages of Shuangpengxi granodiorite and Xiekeng gabbro diorite at ca. 239-245 Ma and 235-246 Ma. Huang et al. [45] subsequently gave the age of Shehaliji quartz monzonite at ca. 234-235 Ma. Li et al. [15] measured ages of emplacement of the Tongren granodiorite (238-242) Ma, Ayishan granitoid (238-242 Ma), Meiwu granitoid (243-251 Ma) and Dewulu granitoid (238-247 Ma). Qiu and Deng [6] reported that the dioritic MME of Dewulu intrusive complex yields an age of $247.0 \pm 2.2 \mathrm{Ma}$. Sui et al. [8] also reported ages of granodiorite, quartz diorite porphyry, and diorite porphyry dike in Zaozigou deposit at 248.9 $\pm 1.4 \mathrm{Ma}$, $244.8 \pm 1.4 \mathrm{Ma}$, and $237.5 \pm 1.4 \mathrm{Ma}$, respectively. Combining the geochronology of the ore-hosting porphyritic dacite emplacement at 246.1 $\pm 5.2 \mathrm{Ma}$ and 248.1 $\pm 3.8 \mathrm{Ma}$ in the Zaozigou deposit presented in this study, in conjunction with the data from previously published articles, we propose that Triassic magmatism widespread in the Tongren-Xiahe-Hezuo area, including batholiths, stocks, sills, and dikes, mainly formed at ca. 248-235 Ma.

Several geochronological data focused on the age of metamorphism in the Qinling orogen have been published in the past decade. The earliest precise estimated ages came from ${ }^{39} \mathrm{Ar} /{ }^{40} \mathrm{Ar}$ of phengites and riebeckites, giving well-defined age plateaus of $236 \pm 5 \mathrm{Ma}$ and $217 \pm 8 \mathrm{Ma}$, respectively [46]. Li et al. [47] employed the whole rock $\mathrm{Sm}-\mathrm{Nd}$ and $\mathrm{Rb}-\mathrm{Sr}$ isochron on schist and reported ages of $242 \pm 21 \mathrm{Ma}$ and $221 \pm 13 \mathrm{Ma}$. Another estimate of $214 \pm 11 \mathrm{Ma}$ was made from $\mathrm{U}-\mathrm{Pb}$ zircon analysis on granulites, representing the age of retrograde metamorphism in amphibolite facies rocks [48]. Consequently, the age of peak metamorphism in the studied area is $\sim 220 \mathrm{Ma}$. Sui et al. [8] and Sui and Li [17] reported ${ }^{40} \mathrm{Ar} /{ }^{39} \mathrm{Ar}$ plateau ages of $245.6 \pm 1.0 \mathrm{Ma}$, $242.1 \pm 1.0 \mathrm{Ma}, 230 \pm 2.3 \mathrm{Ma}$, and $219.4 \pm 1.1 \mathrm{Ma}$ for sericite from porphyritic dacite and quartz diorite porphyry. The first three ages are consistent with zircon $\mathrm{U}-\mathrm{Pb}$ ages, representing emplacement of Triassic magmatism. The latter age is close to the metamorphic peak and may represent the mineralization age. Therefore, the ages of $\sim 225 \mathrm{Ma}$ and $\sim 203 \mathrm{Ma}$ in the ore-hosting porphyritic dacite are interpreted to be influenced by hydrothermal events related to metamorphism.

\subsection{Petrogenesis of Early Triassic Magmatism in Tongren-Xiahe-Hezuo Area}

The Lu-Hf isotope system is a very sensitive geochemical tracer to detect the evolutionary history of crustal and mantle material [35-37,49]. Hafnium is partitioned more strongly into melts than Lu during partial melting; therefore the crust generally has lower ${ }^{176} \mathrm{Lu} /{ }^{177} \mathrm{Hf}$ and ${ }^{176} \mathrm{Hf} /{ }^{177} \mathrm{Hf}$ ratios than the mantle. Accordingly, high values of ${ }^{176} \mathrm{Hf} /{ }^{177} \mathrm{Hf}$ (i.e., positive $\varepsilon_{\mathrm{Hf}}(\mathrm{t})$ values) are considered to be sourced from the partial melting of juvenile crustal materials, or directly via mantle-derived mafic melts [49-51]. Low values of ${ }^{176} \mathrm{Hf} /{ }^{177} \mathrm{Hf}$ (i.e., negative $\varepsilon_{\mathrm{Hf}}(\mathrm{t})$ values) indicate old crust input $[35,49-51]$. The $\varepsilon_{\mathrm{Hf}}(\mathrm{t})$ values of magmatic zircons from Zaozigou ore-hosting porphyritic dacite range from -12.5 to -8.9 , with corresponding the zircon two-stage model ages $\left(\mathrm{T}_{\mathrm{DM}^{2}}\right)$ of $2.08-1.84$ Ga. These analyses plot below the chondrite uniform reservoir (CHUR) line (Figure 10A), and within the area of reworked ancient lower crust (Figure 10B), which indicates that the magma could be derived from partial melting of Paleoproterozoic lower crustal material [6]. This interpretation is further supported by data presented in this article indicating that most of the inherited zircons being crystallized in Paleoproterozoic (Table 1).

The $\varepsilon_{\mathrm{Hf}}(\mathrm{t})$ and $\mathrm{T}_{\mathrm{DM}}{ }^{2}$ values are similar to the Shuangpengxi granodiorites $\left(\varepsilon_{\mathrm{Hf}}(\mathrm{t})=-4.7 \sim-3.6\right.$; $\left.\mathrm{T}_{\mathrm{DM}^{2}}=1.49 \sim 1.57 \mathrm{Ga}\right)$ [14], Xiahe granodiorites $\left(\varepsilon_{\mathrm{Hf}}(\mathrm{t})=-11.0 \sim-4.0 ; \mathrm{T}_{\mathrm{DM}}{ }^{2}=1.53 \sim 1.97 \mathrm{Ga}\right)$ [52], Tongren granodiorites $\left(\varepsilon_{\mathrm{Hf}}(\mathrm{t})=-5.8 \sim-0.6 ; \mathrm{T}_{\mathrm{DM}}{ }^{2}=1.32 \sim 1.64 \mathrm{Ga}\right)$ [15], and Dewulu intrusive complex 
$\left(\varepsilon_{\mathrm{Hf}}(\mathrm{t})=-8.0 \sim-3.3 ; \mathrm{T}_{\mathrm{DM}^{2}}=1.48 \sim 1.78 \mathrm{Ga}\right)[6]$, but different from the Xiekeng high-Mg and high-Al diorites $\left(\varepsilon_{\mathrm{Hf}}(\mathrm{t})=0.2 \sim 5.3 ; \mathrm{T}_{\mathrm{DM}^{2}}=0.93 \sim 1.26 \mathrm{Ga}\right)$ [14]. Qiu and Deng [6] thus suggested that the magmas of Early Triassic magmatism were probably derived from a heterogeneous source that included both crustal and mantle components.

This hypothesis was further supported by the bulk geochemical signature of widespread magmatism coeval with the ore-hosting porphyritic dacite in the Tongren-Xiahe-Hezuo area. Luo et al. [14] reported the geochemical and Sr-Nd-Hf isotopic compositions of the Shuangpengxi granodiorite and proposed that the magma was derived from partial melting of crustal materials. Li et al. [15] suggest that the magma of the Tongren granodiorite was generated by dehydration melting of a mafic lower crustal component with additional input of a mafic component derived from the subcontinental lithospheric mantle. These geochemical traits suggest that the Early Triassic magmatism in Tongren-Xiahe-Hezuo area originated from the reworking of Mesoproterozoic to Paleoproterozoic ancient crust and partial melting of Neoproterozoic juvenile crust [6,35].

\subsection{Implications on Links between Magmatism and Mineralization}

The Zaozigou deposit has been controversial in its classification and remains one of the more difficult ore systems to fully understand in the West Qinling. The deposit shows a spatial association with Triassic dikes and sills. The broad spatial association between gold and magmatism has been argued as genetically important by some workers. Liu et al. [16] concluded that the ore-forming fluids were of a magmatic-hydrothermal origin based upon hydrogen, oxygen, and sulfur isotopic compositions. They further proposed that the Zaozigou deposit is a porphyry-type gold deposit related to a diorite porphyry, and therefore a ca. 216 Ma date for magmatic zircon records the age of the $\mathrm{Au}-\mathrm{Sb}$ ore formation. However these 'magmatic' zircons yield CL textures and compositions that could correspond to overprints from a younger hydrothermal event. Dai and Chen [53] argued for a genetic relationship between Triassic magmatism and $\mathrm{Au}-\mathrm{Sb}$ mineralization based on geological and geochemical characteristics. A recent ${ }^{40} \mathrm{Ar} /{ }^{39} \mathrm{Ar}$ plateau ages of $245.6 \pm 1.0 \mathrm{Ma}$ and $242.1 \pm 1.0 \mathrm{Ma}$ for hydrothermal sericite, which are bracketed by zircon $\mathrm{U}-\mathrm{Pb}$ ages on pre- and post-ore dikes, were used to argue for a significantly older mineralizing event [8]. Sui et al. [8] further defined Zaozigou as a reduced intrusion-related gold system (RIRGS) on the basis of interpreted overlapping formation ages of igneous host rocks and gold mineralization.

Magmatic oxygen fugacity is a key factor that controls the formation of porphyry deposits [39,54]. Most researchers agree that oxidized magmas can hold high metal contents and are favorable for the generation of porphyry deposits [54]. In general, oxygen fugacities of $>F M Q+2$ are necessary for the formation of economic porphyry $\mathrm{Cu}(\mathrm{Au})$ deposits and $\mathrm{FMQ}+1.5$ is a threshold for any porphyry deposit [54]. As shown in this study, the ore-bearing porphyritic dacites have very low oxygen fugacity, with $\triangle \mathrm{FMQ}$ ranging from -4.61 to -2.56 . Under the low oxygen fugacities, it would have been difficult to release metals out of the melt and instead magmas would have become sulfide-saturated during evolution in deep magma chambers [54]. A dozen of porphyry-skarn $\mathrm{Cu}(\mathrm{Au})$ deposits are hosted in the granitic intrusions and adjacent rock in northeastern part of Tongren-Xiahe-Hezuo area (Figure 1B). Oxygen fugacity from ore-bearing porphyries shows FMQ \pm 3.3 [6], significantly higher than the porphyritic dacites at Zaozigou. In addition, hydrothermal alteration in porphyry deposits typically shows distinct temporal and spatial evolution and zonation from early, proximal, high-temperature potassic alteration to sericitic alteration to low-temperature, distal, advanced argillic and intermediate argillic alteration. However, the orebodies at Zaozigou are characterized by strong wallrock sulfidation (pyrite, arsenopyrite, and stibnite) and discrete proximal sericitized, silicified, and carbonatized alteration haloes (Figure 3). Such alteration haloes are easily distinguished from typical porphyry alteration profiles by their size and distinct alteration boundaries. Additionally, ${ }^{40} \mathrm{Ar} /{ }^{39} \mathrm{Ar}$ geochronology on hydrothermal sericite indicates the gold event may have formed at $219 \mathrm{Ma}$ [17], 17-28 Ma later than the emplacement of Triassic porphyritic dacite. 
Reduced Intrusion-Related Gold Systems have become a new exploration target deposit model for low-grade, large-tonnage gold deposits $[22,55,56]$. The best recognized examples of such deposits occur in Fort Knox in Alaska, Dublin Gulch, and Scheelite Dome in Yukon [22]. Comparisons of Zaozigou with these deposits reveals some similarities but critical differences. Important similarities include that the plutons are typically small and are dominated by felsic magmatic phases, the metal assemblages are $\mathrm{Au}-\mathrm{Sb}-\mathrm{As}-\mathrm{Hg}$, and the oxidation state of igneous rock are mostly at or below the FMQ oxide buffer $[55,56]$. Despite these similarities, significant characteristics that contrast with those of RIRGS include: (1) Typical RIRGS form in igneous rocks emplaced into a deformed continental margin backstop but are not products of arc magmatism and volcanic rocks are rare. The Zaozigou intrusions are products of arc magmatism and volcanic rocks are well developed. (2) The sulfide content of RIRGS is extremely low, commonly $<1 \mathrm{vol} . \%$, but Zaozigou is characterized by massive and economic stibnite (Figure 3G,H). (3) The RIRGS are characterized by reduced mineral assemblage containing pyrrhotite and minor loellingite [22]. In contrast, these reduced minerals are rare in Zaozigou. (4) The distinctive mineralization style of RIRGS is sheeted veins, which are composed of parallel, low grades $(<1 \mathrm{~g} / \mathrm{t} \mathrm{Au})$, single stage quartz veins. Nevertheless, the ore-bearing zone at Zaoaigou comprises massive auriferous calcite vein (Figure 3E,F) and stibnite-quartz-native gold veins (Figure 3G,H). (5) Exsolution of hydrothermal fluids directly from the emplacement of the porphyritic dacites at Zaozigou is unlikely given the 219 Ma gold metallogenic events occurred $20 \mathrm{Ma}$ or so later than the emplacement of the intrusions. As a result, the Zaozigou deposit is not likely to be genetically related to the reduced intrusions, and therefore should not be considered a Reduced Intrusion-Related Gold System.

\section{Conclusions}

(1) Zircon U-Pb dating indicates that the ore-hosting porphyritic dacite was formed at 246-248 Ma. The magma of Early to Middle Triassic porphyritic dacite could be derived from partial melting of Paleoproterozoic crustal materials.

(2) The emplacement of the Triassic porphyritic dacite was approximately 20 Ma earlier than the economic mineralization at Zaozigou. Oxygen fugacity of porphyritic dacite lower than FMQ and undeveloped typical porphyry alteration zones indicate that Zaozigou is not a porphyry-type deposit. In addition, massive sulfide minerals preclude the possibility that the Zaozigou is a reduced intrusion-related gold system. The new finding that the Zaozigou deposit is not likely to be genetically related to the magmatism will provide us with new ideas for prospecting. It allows explorers to concentrate prospecting on local and regional structures to vector prospective targets rather than focusing on magmatic rocks.

Supplementary Materials: The following are available online at http:/ / www.mdpi.com/2075-163X/9/1/37/s1, Computer Code S1: OFnum1.0. Algorithms based on Matlab software for calculating $\mathrm{fO}_{2}$.

Author Contributions: Conceptualization, K.-F.Q.; Data curation, H.-C.Y.; Funding acquisition, N.-B.L.; Investigation, H.-C.Y., K.-F.Q., Z.-Y.G., D.M., G.-P.J., and R.Z.; Methodology, H.-C.Y., K.-F.Q., Z.-Y.G., and J.-Z.G.; Project administration, K.-F.Q. and N.-B.L.; Resources, G.-P.J. and R.Z.; Software, C.-A.G. and Y.P.; Writing —original draft, H.-C.Y. and K.-F.Q.; Writing—review \& editing, H.-C.Y., K.-F.Q., and D.M.

Funding: This research was funded by the National Natural Science Foundation of China (41702069), China Postdoctoral Science Foundation (2016M591221, 20170108), CAS Key Laboratory of Mineralogy and Metallogeny (KLMM20170201), and State Key Laboratory of Geological Processes and Mineral Resources (MSFGPMR201804).

Acknowledgments: The authors are very grateful for the logistic assistance from the management of Zaozigou Gold Company. The authors also would like to thank Richard Goldfarb, Xue Gao, and Yun-Chuan Zeng at the China University of Geoscience in Beijing for constructive discussion on the formatting and preparation of this manuscript.

Conflicts of Interest: The authors declare no conflict of interest. 


\section{References}

1. Deng, J.; Wang, Q.F. Gold mineralization in China: Metallogenic provinces, deposit types and tectonic framework. Gondwana Res. 2016, 36, 219-274. [CrossRef]

2. Yang, L.Q.; Deng, J.; Dilek, Y.; Qiu, K.F.; Ji, X.Z.; Li, N.; Taylor, R.D.; Yu, J.Y. Structure, geochronology, and petrogenesis of the Late Triassic Puziba granitoid dikes in the Mianlue suture zone, Qinling Orogen, China. Geol. Soc. Am. Bull. 2015, 11/12, 1831-1854. [CrossRef]

3. Yang, L.Q.; Deng, J.; Qiu, K.F.; Ji, X.Z.; Santosh, M.; Song, K.R.; Song, Y.H.; Geng, J.Z.; Zhang, C.; Hua, B. Magma mixing and crust-mantle interaction in the Triassic monzogranites of Bikou Terrane, central China: Constraints from petrology, geochemistry, and zircon U-Pb-Hf isotopic systematics. J. Asian Earth Sci. 2015, 98, 320-341. [CrossRef]

4. Dong, Y.P.; Santosh, M. Tectonic architecture and multiple orogeny of the Qinling Orogenic Belt, Central China. Gondwana Res. 2016, 29, 1-40. [CrossRef]

5. Duan, M.; Niu, Y.L.; Kong, J.J.; Sun, P.; Hu, Y.; Zhang, Y.; Chen, S.; Li, J.Y. Zircon U-Pb geochronology, Sr-Nd-Hf isotopic composition and geological significance of the Late-Triassic Baijiazhuang and Lvjing granitic plutons in West Qinling Orogen. Lithos 2016, 260, 443-456. [CrossRef]

6. Qiu, K.F.; Deng, J. Petrogenesis of granitoids in the Dewulu skarn copper deposit: Implications for the evolution of the Paleotethys ocean and mineralization in Western Qinling, China. Ore Geol. Rev. 2017, 90, 1078-1098. [CrossRef]

7. Qiu, K.F.; Yu, H.C.; Gou, Z.Y.; Liang, Z.L.; Zhang, J.L.; Zhu, R. Nature and origin of Triassic igneous activity in the Western Qinling Orogen: The Wenquan composite pluton example. Int. Geol. Rev. 2018, 60, 242-266. [CrossRef]

8. Sui, J.X.; Li, J.W.; Jin, X.Y.; Vasconcelos, P.; Zhu, R. ${ }^{40} \mathrm{Ar} /{ }^{39} \mathrm{Ar}$ and U-Pb constraints on the age of the Zaozigou disseminated gold deposit, Xiahe-Hezuo district, West Qinling orogen, China: Implications for the early Triassic reduced intrusion-related gold metallogeny. Ore Geol. Rev. 2018, in press. [CrossRef]

9. Qiu, K.F.; Deng, J.; Taylor, R.D.; Song, K.R.; Song, Y.H.; Li, Q.Z.; Goldfarb, R.J. Paleozoic magmatism and porphyry $\mathrm{Cu}$-mineralization in an evolving tectonic setting in the North Qilian Orogenic Belt, NW China. J. Asian Earth Sci. 2016, 122, 20-40. [CrossRef]

10. Qiu, K.F.; Marsh, E.; Yu, H.C.; Pfaff, K.; Gulbransen, C.; Gou, Z.Y.; Li, N. Fluid and metal sources for the Wenquan porphyry molybdenite deposit, Western Qinling, NW China. Ore Geol. Rev. 2017, 86, 459-473. [CrossRef]

11. Qiu, K.F.; Taylor, R.D.; Song, Y.H.; Yu, H.C.; Song, K.R.; Li, N. Geologic and geochemical insights into the formation of the Taiyangshan porphyry copper-molybdenum deposit, Western Qinling Orogenic Belt, China. Gondwana Res. 2016, 35, 40-58. [CrossRef]

12. Li, N.; Chen, Y.J.; Santosh, M.; Pirajno, F. Compositional polarity of Triassic granitoids in the Qinling orogen, China: Implication for termination of the northernmost paleo-Tethys. Gondwana Res. 2016, 27, $244-257$. [CrossRef]

13. Zhang, H.F.; Jin, L.L.; Zhang, L.; Harris, N. Geochemical and Pb-Sr-Nd isotopic compositions of granitoids from western Qinling belt: Constraints on basement nature and tectonic affinity. Sci. China (Ser. D): Earth Sci. 2007, 50, 184-196. [CrossRef]

14. Luo, B.J.; Zhang, H.F.; Lü, X.B. U-Pb zircon dating, geochemical and Sr-Nd-Hf isotopic compositions of Early Indosinian intrusive rocks in West Qinling, central China: Petrogenesis and tectonic implications. Contrib. Mineral. Petrol. 2012, 164, 551-569. [CrossRef]

15. Li, X.W.; Mo, X.X.; Huang, X.F.; Dong, G.C.; Yu, X.H.; Luo, M.F.; Liu, Y.B. U-Pb zircon geochronology, geochemical and Sr-Nd-Hf isotopic compositions of the Early Indosinian Tongren Pluton in West Qinling: Petrogenesis and geodynamic implications. J. Asian Earth Sci. 2015, 97, 38-50. [CrossRef]

16. Liu, Y.; Liu, Y.H.; Dong, F.C.; Li, Z.H.; Yu, J.K.; Ma, X.P. Accurate dating of mineralogenetic epoch and its geological significance in Zaozigou gold deposit, Gansu Province. Gold 2012, 33, 10-17. (In Chinese with English Abstract)

17. Sui, J.Z.; Li, J.W. Geochronology and genesis of the Zaozigou gold deposit, Xiahe-Hezuo district, West Qinling. Acta Mineral. Sin. 2013, 346-347. (In Chinese)

18. Liang, Z.L.; Chen, G.Z.; Ma, H.S.; Zhang, Y.N. Evolution of Ore-controlling Faults in the Zaozigou Gold Deposit, Western Qinling. Geotectonica et Metallogenia 2016, 40, 354-366. 
19. Wei, L.X.; Chen, Z.L.; Pang, Z.S.; Han, F.B.; Xiao, C.H. An Analysis of the Tectonic Stress Field in the Zaozigou Gold Deposit, Hezuo Area, Gansu Province. Aeta Geosci. Sin. 2018, 39, 79-93. (In Chinese with English Abstract)

20. Goldfarb, R.J.; Qiu, K.F.; Deng, J.; Chen, Y.J.; Yang, L.Q. Orogenic Gold Deposits of China. Econ. Geol. 2019, unpublished.

21. Seedorff, E.; Dilles, J.H.; Proffett, J.M., Jr.; Einaudi, M.T.; Zurcher, L.; Stavast, W.J.A.; Johnson, D.A.; Barton, M.D. Porphyry Deposits: Characteristics and Origin of Hypogene Features. Econ. Geol. 2005, 100, 251-298.

22. Hart, C.J.R.; Goldfarb, R.J. Distinguishing intrusion-related from orogenic gold systems. In Proceedings of the New Zealand Minerals Conference, Auckland, New Zealand, 13-16 November 2005; pp. 125-133.

23. Goldfarb, R.J.; Baker, T.; Dube, B.; Groves, D.I.; Hart, C.J.R.; Gosselin, P. Distribution, character and genesis of gold deposits in metamorphic terranes. Econ. Geol. 2005, 100, 407-450.

24. Dong, Y.P.; Yang, Z.; Liu, X.M.; Sun, S.S.; Li, W.; Cheng, B.; Zhang, F.F.; Zhang, X.N.; He, D.F.; Zhang, G.W. Mesozoic intracontinental orogeny in the Qinling Mountains, central China. Gondwana Res. 2016, 30, 144-158. [CrossRef]

25. Deng, J.; Wang, Q.F.; Li, G.J.; Santosh, M. Cenozoic tectono-magmatic and metallogenic processes in the Sanjiang region, southwestern China. Earth-Sci. Rev. 2014, 138, 268-299. [CrossRef]

26. Deng, J.; Wang, C.M.; Bagas, L.; Carranza, E.J.M.; Lu, Y.J. Cretaceous-Cenozoic tectonic history of the Jiaojia Fault and gold mineralization in the Jiaodong Peninsula, China: Constraints from zircon U-Pb, illite K-Ar, and apatite fission track thermochronometry. Miner. Depos. 2015, 50, 987-1006. [CrossRef]

27. Yang, L.Q.; Deng, J.; Wang, Z.L.; Guo, L.N.; Li, R.H.; Groves, D.I.; Danyushevsky, L.V.; Zhang, C.; Zheng, X.L.; Zhao, H. Relationships between gold and pyrite at the Xincheng gold deposit, Jiaodong Peninsula, China: Implications for gold source and deposition in a brittle epizonal environment. Econ. Geol. 2016, 111, 105-126. [CrossRef]

28. Yang, L.Q.; Deng, J.; Goldfarb, R.J.; Zhang, J.; Gao, B.F.; Wang, Z.L. ${ }^{40} \mathrm{Ar} /{ }^{39}$ Ar geochronological constraints on the formation of the Dayingezhuang gold deposit: New implications for timing and duration of hydrothermal activity in the Jiaodong gold province, China. Gondwana Res. 2014, 25, 1469-1483. [CrossRef]

29. Cao, X.F.; Mohaed, L.S.S.; Lü, X.B.; He, M.C.; Chen, C.; Zhu, J.; Tang, R.K.; Liu, Z.; Zhang, B. Ore-Forming Process of the Zaozigou Gold Deposit: Constraints from Geological characteristics, gold occurrence and stable isotope compositions. J. Jilin Univ. (Earth Sci. Ed.) 2012, 42, 1040-1054. (In Chinese with English Abstract)

30. Dai, W.J.; Chen, Y.Y.; Liu, D.X.; Ma, X.Y. Wallrock alteration and gold mineralization in zaozigou gold mine of gansu province. Gansu Geol. 2011, 20, 31-36. (In Chinese with English Abstract)

31. Liang, Z.L.; Zhang, Y.N.; Wang, J.L.; Wang, H.T. Geology feature and deep prospection analysis of Zaozigou gold deposit. Gansu Metall. 2012, 34, 64-69.

32. Zhang, T.; Chen, Z.L.; Xiao, C.H.; Liang, Z.L.; Zhou, Z.J.; Han, F.B.; Wei, L.X.; Hou, C.T. The characteristics of mesozonic magmatic rocks and its relation with gold mineralization in Xiahe-Hezuo area, Gansu province. J. Mineral. Petrol. 2017, 37, 40-51. (In Chinese with English Abstract)

33. Yin, Y. Relation of dike rock and gold mineralization in West Qinling region. Gansu Geol. 2011, $20,28-37$. (In Chinese with English Abstract)

34. Anderson, T. Correction of common lead in $\mathrm{U}-\mathrm{Pb}$ analyses that do not report ${ }^{204} \mathrm{~Pb}$. Chem. Geol. 2002, 192, 59-79. [CrossRef]

35. Geng, J.Z.; Qiu, K.F.; Gou, Z.Y.; Yu, H.C. Tectonic regime switchover of Triassic Western Qinling Orogen: Constraints from LA-ICP-MS zircon U-Pb geochronology and Lu-Hf isotope of Dangchuan intrusive complex in Gansu, China. Chemie der Erde-Geochem. 2017, 77, 637-651. [CrossRef]

36. Li, C.Y.; Zhang, R.Q.; Ding, X.; Ling, M.X.; Fan, W.M.; Sun, W.D. Dating cassiterite using laser ablation Icp-Ms. Ore Geol. Rev. 2016, 72, 313-322. [CrossRef]

37. Zhang, R.Q.; Lu, J.J.; Lehmann, B.; Li, C.Y.; Li, G.L.; Zhang, L.P.; Guo, J.; Sun, W.D. Combined zircon and cassiterite $\mathrm{U}-\mathrm{Pb}$ dating of the Piaotang granite-related tungsten-tin deposit, southern Jiangxi tungsten district, China. Ore Geol. Rev. 2017, 82, 268-284. [CrossRef]

38. Zou, X.Y.; Qin, K.Z.; Han, X.L.; Li, G.M.; Evans, N.J.; Li, Z.Z.; Yang, W. Insight into zircon REE oxy-barometers: A lattice strain model perspective. Earth Planet. Sci. Lett. 2019, 56, 87-96. [CrossRef]

39. Smythe, D.J.; Brenan, J.M. Magmatic oxygen fugacity estimated using zircon-melt partitioning of cerium. Earth Planet. Sci. Lett. 2016, 453, 260-266. [CrossRef] 
40. Ballard, J.R.; Palin, M.J.; Campbell, I.H. Relative oxidation states of magmas inferred from Ce(IV)/Ce(III) in zircon: Application to porphyry copper deposits of northern Chile. Contrib. Mineral. Petrol. 2002, 144, 347-364. [CrossRef]

41. Ferry, J.M.; Watson, E.B. New thermodynamic models and revised calibrations for the Ti-in-zircon and Zr-in-rutile thermometers. Contrib. Mineral. Petrol. 2007, 154, 429-437. [CrossRef]

42. Virgo, D.; Mysen, B.O.; Kushiro, I. Anionic constitution of 1-atmosphere silicate melts: Implications for the structure of igneous melts. Science 1980, 208, 1371-1373. [CrossRef]

43. Hou, Z.Q.; Yang, Z.M.; Lu, Y.J.; Kemp, A.; Li, Q.Y.; Tang, J.X.; Yang, Z.S.; Duan, L.F. A genetic linkage between subduction- and collision-related porphyry $\mathrm{Cu}$ deposits in continental collision zones. Geology 2015, 43, 643-650. [CrossRef]

44. Jin, W.J.; Zhang, Q.; He, D.F.; Jia, X.Q. SHRIMP dating of adakites in western Qinling and their implications. Acta Petrol. Sin. 2005, 21, 959-966. (In Chinese with English Abstract)

45. Huang, X.F.; Mo, X.X.; Yu, X.H.; Li, X.W.; Ding, Y.; Wei, P.; He, W.Y. Zircon U-Pb chronology, geochemistry of the Late Triassic acid volcanic rocks in Tanchang area, West Qinling and their geological significance. Acta Petrol. Sin. 2013, 29, 3968-3980. (In Chinese with English Abstract)

46. Mattauer, M.; Matte, P.; Malavieille, J.; Tapponnier, P.; Maluski, H.; Qin, X.Z.; Lun, L.Y.; Qin, T.Y. Tectonics of Qinling Belt: Build-up and evolution of eastern Asia. Nature 1985, 317, 496-500. [CrossRef]

47. Li, S.G.; Sun, W.D.; Zhang, G.W.; Chen, J.Y.; Yang, S.C. Chronology and geochemistry of metamorphic volcanic rocks in Heigouxia, South Qinling. Sci. Chine Earth Sci. 1996, 26, 223-230. (In Chinese)

48. Liang, S.; Liu, L.; Zhang, C.L.; Yang, Y.C.; Yang, W.Q.; Kang, L.; Cao, Y.T. Metamorphism and zircon U-Pb age of high-pressure mafic granulites in in Mian-Lüe suture zone, South Qinling orogen. Acta Petrol. Sin. 2013, 29, 1657-1674.

49. Blichert-Toft, J.; Albarède, F. The Lu-Hf isotope geochemistry of chondrites and the evolution of the mantle-crust system. Earth Planet. Sci. Lett. 1997, 148, 243-258. [CrossRef]

50. Belousova, E.A.; Griffin, W.L.; O'Reilly, S.Y. Zircon crystal morphology, trace element signatures and hf isotope composition as a tool for petrogenetic modelling: Examples from eastern australian granitoids. J. Petrol. 2005, 47, 329-353. [CrossRef]

51. Mahdavi, A.; Karimpour, M.H.; Mao, J.W.; Shahri, M.R.H.; Shafaroudi, A.M.; Li, H.Y. Zircon U-Pb geochronology, $\mathrm{Hf}$ isotopes and geochemistry of intrusive rocks in the gazu copper deposit, Iran: Petrogenesis and geological implications. Ore Geol. Rev. 2016, 72, 818-837. [CrossRef]

52. Wei, P.; Mo, X.X.; Yu, X.H.; Huang, X.F.; Ding, Y.; Li, X.W. Geochemistry, chronology and geological significance of the granitoids in Xiahe, West Qinling. Acta Geol. Sin. 2013, 29, 3981-3992. (In Chinese with English Abstract)

53. Dai, W.J.; Chen, Y.Y. Relationship between neutral rock vine and mineralization in Zaozigou gold deposit, Gansu. Gold 2012, 33, 19-23. (In Chinese with English Abstract)

54. Zhang, C.C.; Sun, W.D.; Wang, J.T.; Zhang, L.P.; Sun, S.J.; Wu, K. Oxygen fugacity and porphyry mineralization: A zircon perspective of Dexing porphyry $\mathrm{Cu}$ deposit, China. Geochim. Cosmochim. Acta 2017, 206, 342-363. [CrossRef]

55. Qiu, K.F. Geological and geochemical characteristics of reduced intrusion-related gold system. Geol. Rev. 2013, 59, 590-591. (In Chinese)

56. Mériaud, N.; Jébrak, M. From intrusion-related to orogenic mineralization: The Wasamac deposit, Abitibi Greenstone Belt, Canada. Ore Geol. Rev. 2017, 84, 289-308. [CrossRef]

(C) 2019 by the authors. Licensee MDPI, Basel, Switzerland. This article is an open access article distributed under the terms and conditions of the Creative Commons Attribution (CC BY) license (http:// creativecommons.org/licenses/by/4.0/). 